\title{
Preliminary Performance Evaluation of the Gold Nanoparticle Method for Quantification of Residual Poly-(Diallyldimethyl Ammonium Chloride) in Treated Waters in the Umgeni Water Catchment, Kwazulu-Natal (South Africa)
}

\section{Manickum $\mathbf{T}^{1 *}$, John $\mathbf{W}^{1}$, Toolsee $\mathbf{N}^{2}$ and Rachi Rajagopaul}

${ }^{1}$ Scientific Services Laboratories: Chemical Sciences, Engineering and Scientific Services Division, Umgeni Water, 310 Burger Street, Pietermaritzburg 3201 , KwaZuluNatal, South Africa

${ }^{2}$ Wiggins Process Evaluation Facility, Wiggins Water Works, 251 Wiggins Road, Mayville, Engineering \& Scientific Services Division, Umgeni Water, KwaZulu-Natal, South Africa

\begin{abstract}
A "real world" study to assess the performance characteristics (precision, accuracy) of the citrate-capped, gold nanoparticle, Ultraviolet-Visible colorimetric method, for quantifying residual poly-diallyl dimethylammonium chloride (poly-DADMAC) in four raw dam and treated potable waters, was undertaken. Using three calibration methods, the method was found to be sensitive (LOQ=2 $\mu \mathrm{g} / \mathrm{L})$, over the linear range $10-30 \mu \mathrm{g} / \mathrm{L}$. The overall mean within-batch precision (\%RSD) was: $7.42( \pm 7.07)$ for Method 1, and $7.66( \pm 7.37)$ for Method 2; between-batch (reproducibility) $(\%$ RSD) was $54.37 \pm 30.03$ ) and $35.89 \pm 34.89$ ). Statistical data analysis indicated fairly good agreement (no significant difference) for poly-DADMAC levels in 30 samples analyzed by the two methods Method 1 and 2 . The residual poly-DADMAC potable water levels (range: $<2-8 \mu \mathrm{g} / \mathrm{L})$, were: on average $( \pm S D)(\mu \mathrm{g} / \mathrm{L}), 1.21( \pm 1.31)$ for Hazelmere Dam, $1.22( \pm 0.55)$ for Midmar Dam, $3.40 \pm 3.89)$ for Inanda Dam, and $3.64( \pm 3.83)$ for Nagel Dam. The observed, apparent poly-DADMAC levels, obtained by Method 1, (range: 6-16 $\mu \mathrm{g} / \mathrm{L})$ were, on average $( \pm S D)(\mu \mathrm{g} / \mathrm{L})$, for the raw water samples: $3.73( \pm 0.46)$ for Inanda Dam, $5.73( \pm 6.57)$ for Nagle Dam, $6.82( \pm 9.03)$ for Hazelmere Dam and 10.12 ( \pm 6.94$)$ for Midmar Dam. The study indicated compliance of all treated, potable water for residual poly-DADMAC, to the current international limit of $\leq 50 \mu \mathrm{g} / \mathrm{L}$. The relatively high apparent concentration (range: $<2-24$ $\mu \mathrm{g} / \mathrm{L}$ ) of poly-DADMAC observed on the raw dam waters was attributed to the presence of Natural Organic Matter (NOM).
\end{abstract}

Keywords: Citrate-capped gold nanoparticle; Water treatment polymer; Poly-(diallyldimethylammonium chloride); Residual polyelectrolyte; Colorimetry; Ultraviolet-visible spectroscopy; Natural organic matter; Disinfection by-product; Toxicity; N-nitrosodimethylamine

\section{Introduction}

Poly-diallyldimethylammonium chloride (poly-DADMAC) is one of the most commonly used organic polyelectrolytes in wastewater and potable water treatment plants, as a coagulant and as a flocculent aid, for floc formation and for improved settling of larger particles [1-5]. Due to its potential to form N-nitrosodimethylamine (NDMA) [6-8], there has been, in recent years, a growing concern over the fate of polyDADMAC within the water treatment process. Some early work has demonstrated that NDMA is a disinfection by-product formed during chlorination steps within the water treatment process [9].

Furthermore, NDMA is a suspected carcinogen [1,6,8,10,11]. The presence of residual poly-DADMAC depends on its reactivity during the disinfection processes, and whether it degrades into toxic compounds, or other by-products, that pass through the various stages in the water treatment process. Due to the highly charged nature the main assumption is that it will be removed together with the sludge during flocculation in the water treatment process.

Personal care products are another source of polyelectrolytes that can enter the environment and water treatment facilities, where they may not be adequately removed in the water treatment process $[12,13]$. Residual amounts may persist if the incorrect dose is used. The American Water Works Association (AWWA), American Society for Testing Materials, The European Committee for Standardization, the National Sanitation Foundation International, and the American
National Standards Institute, provide standards for the maximum dosage of polyelectrolytes $(10-100 \mathrm{mg} / \mathrm{L})$ that can be used in water treatment. They have set the residual amount of poly-DADMAC in drinking water at $50 \mu \mathrm{g} / \mathrm{L}[3,14,15]$. Recent work has shown that polyelectrolytes, like poly-DADMAC, can be toxic to aquatic organisms at levels above $50 \mu \mathrm{g} / \mathrm{L}[12,13]$.

Thus, for water treatment plants using poly-DADMAC as coagulant, and from an environmental, human health perspective, there is a strong requirement to determine the amount of residual polyelectrolytes, like poly-DADMAC, in the drinking water. To monitor residual concentrations in water, down to the required limit of $\leq 50 \mu \mathrm{g} / \mathrm{L}$, sensitive analytical methods are therefore required.

Colloid titration has been used to determine residual polyDADMAC in water samples $[1,2,16]$. However, the sensitivity of such

${ }^{*}$ Corresponding author: Manickum T, Scientific Services Laboratories: Chemical Sciences, Engineering and Scientific Services, Umgeni Water, P.O Box 9, Pietermaritzburg-3200 KwaZulu-Natal, South Africa, Tel: +27333411067; Fax +27333411501; E-mail: thavrin.manickum@umgeni.co.za

Received April 30, 2015; Accepted May 30, 2015; Published June 01, 2015

Citation: Manickum T, John W, Toolsee N, Rajagopaul R (2015) Preliminary Performance Evaluation of the Gold Nanoparticle Method for Quantification of Residual Poly-(Diallyldimethyl Ammonium Chloride) in Treated Waters in the Umgeni Water Catchment, Kwazulu-Natal (South Africa). Hydrol Current Res 6: 206. doi:10.4172/2157-7587.1000206

Copyright: (c) 2015 Manickum T, et al. This is an open-access article distributed under the terms of the Creative Commons Attribution License, which permits unrestricted use, distribution, and reproduction in any medium, provided the original author and source are credited. 
Citation: Manickum T, John W, Toolsee N, Rajagopaul R (2015) Preliminary Performance Evaluation of the Gold Nanoparticle Method for Quantification of Residual Poly-(Diallyldimethyl Ammonium Chloride) in Treated Waters in the Umgeni Water Catchment, Kwazulu-Natal (South Africa). Hydrol Current Res 6: 206. doi:10.4172/2157-7587.1000206

techniques is $0.5-1.0 \mathrm{mg} / \mathrm{L}$. The AWWA standard for poly-DADMAC [17] uses a gravimetric method; the method is long, labor-intensive and cannot be applied to analysis of residues in treated water. The other challenge is that the cationic polymer is ultraviolet (UV) inactive, and it is therefore not possible to employ UV-Visible (Vis) spectrophotometry for its analysis $[18,19]$. Pre- and post-fluorescent tagging of polyDADMAC, with 10-40 $\mu \mathrm{g} / \mathrm{L}$ detection limits in water, was developed by Elridge [4]. However, these methods are complicated, require several pre-treatment steps, can be expensive, are very time-consuming, and may not be suitable for routine analysis. A novel gel permeation chromatography (GPC) method, using RI detection, was developed by W John $[18,19]$, for poly-DADMAC analysis in water, with a detection limit of $50 \mathrm{mg} / \mathrm{L}$, and $1 \%$ precision. A spectrophotometric detection method, of poly-DADMAC, exploiting the flocculation properties using 4-hydroxy-1-napthylazo-benzene-sulfonic acid, which forms a coloured colloid ion pair, was reported by Ndungu et al. [20]. The method had a linear range of 0.1-1.8 $\mathrm{mg} / \mathrm{L}$, with a limit of detection (LOD) of $0.07 \mathrm{mg} / \mathrm{L}$.

Umgeni Water, a bulk potable water supplier, in KwaZulu-Natal $(\mathrm{KZN})$, makes use of this organic polymeric poly-DADMAC as a coagulant in some of its water treatment plants. However, to date the residual amount of poly-DADMAC in the final drinking water from any of the plants using poly-DADMAC, has not been fully investigated or accurately determined. Although we have a state-of-art water testing laboratory at the head office in Pietermaritzburg (KZN), which is ISO/IEC 17025-accredited, and beside the earlier work on analytical method development for quantification of residual poly-DADMAC $[2,18,19]$, there are no automated, rapid, simple "in-house" test methods available, at national, and international, level, for accurate, low level, residual poly-DADMAC analysis in water.

Gumbi et al. [21], from the University of KwaZulu-Natal (South Africa), developed a novel, sensitive spectroscopic technique for polyDADMAC analysis, using citrate-capped gold nanoparticles (Au-NPs), which was applied to analysis of river water samples, with a reported $1-100 \mu \mathrm{g} / \mathrm{L}$ detection range [21]. We hypothesized that this newly developed gold-nanoparticle analytical method would be suitable for the accurate, precise low level quantification $(\leq 50 \mu \mathrm{g} / \mathrm{L})$ of residual poly-DADMAC in treated water. The aim of this study was thus: to evaluate the suitability of the recently reported gold-nanoparticle method [21] for determination of residual poly-DADMAC in typical/real potable, water samples treated with polyelectrolyte-based coagulant: poly-DADMAC; to assess the precision and accuracy of this analytical test method.

We now report on the preliminary performance of this analytical test method. To our knowledge, this is the first report of a "real world" study application of the citrate-capped, Au-NP colorimetric method for quantitation of residual poly-DADMAC in treated, and raw, dam water for potable use.

\section{Materials and Methodology}

\section{Reagents and chemicals}

The three organic polyelectrolyte-based coagulants, containing poly-DADMAC, (with the water works at which it is used) were: Z553D (DV Harris, Wiggins), obtained from Zetchem (KwaZuluNatal, South Africa); SF3456 (Hazelmere water works) and SF3435 (Durban Heights), were obtained from Improchem (KwaZulu-Natal). The composition of the coagulant blends (Aluminium chlorhydrinDADMAC) was unknown due to it being proprietary information.
The Acrodisc premium $25 \mathrm{~mm}$ syringe filter with $\mathrm{GxF} / 0.45 \mu \mathrm{m}$ GHP membrane (HPLC certified - Glass fiber prefilter (GHP: hydrophilic polypropylene, Part Number: AP-4559T) was obtained from Pall life Sciences. Gold (III) chloride tri-hydrate $\left(\mathrm{HAuCl}_{4} \cdot 3 \mathrm{H}_{2} \mathrm{O}\right)$, tri-sodium citrate $(99 \%)\left(\mathrm{Na}_{3} \mathrm{C}_{6} \mathrm{H}_{5} \mathrm{O}_{7} .2 \mathrm{H}_{2} \mathrm{O}\right)$ and poly diallyl dimethyl ammonium chloride (poly-DADMAC) $35 \%$ weight (average molecular weight 100,000) $\left(\mathrm{C}_{6} \mathrm{H}_{16} \mathrm{ClN}\right)$ were obtained from Sigma Aldrich and were of analytical grade. All chemicals were used without further purification. All glassware used was salinized to prevent the adsorption of polyDADMAC and other charged species. Plastic containers were used to store all solutions.

\section{Instrumentation for poly-(DADMAC) analysis}

The Ultraviolet (UV)-Visible (Vis) spectra were measured with an Ocean Optics spectrometer (model HR2000+), equipped with a tungsten halogen (Ocean Optics) based module, and two fiber optic cables (QP 600-2-vis-BX model 727-733-2447, suitable for 400-2100 $\mathrm{nm}$ range, from Narich Ltd (Milnerton, South Africa, agents for Ocean Optics); raw data were captured and analyzed with the spectrometer SpectroSuite ${ }^{R}$ software. Samples were transferred to a $1.0 \mathrm{ml}$ quartz cuvette and placed in the cuvette holder (Ocean Optics CUV-UV with a $1 \mathrm{~cm}$ path length). The light was passed through a fiber optic cable, then the cuvette holder and finally via a second fiber optic cable to the spectrometer.

\section{Instrumentation for physical tests}

For the 51 study samples, the $\mathrm{pH}$, salinity, conductivity, Redox, TDS and temperature, were determined at UKZN. The Redox and $\mathrm{pH}$ were measured with an $827 \mathrm{pH}$ lab meter equipped with a probe (6.0220.100) bought from Metrohm (Switzerland). Salinity, conductivity and total dissolved solids (TDS) were measured with an InoLab ${ }^{\star}$ Cond level 1 (8F93) instrument, equipped with a probe (WTW Tetracon 325), bought from Germany, through Merck. Both probes were conditioned with standards (as per the manufacturer's recommendations) before use every day. Similar physical tests were performed at the Umgeni Water Chemistry laboratory. Turbidity, in Nephelometric Turbidity Units (NTU), was measured with a $\mathrm{HACH}$ 2100 turbidimeter. The total organic carbon (TOC) was measured with a Tekmar Torch analyser, from LabHouse (Midrand, South Africa), agents for Tekmar. The total dissolved solids (TDS) were determined by gravimetry. A JOEL 1010 transmission electron microscope was used for transmission electron microscopy (TEM) analysis of the gold nanoparticles [20]. Samples were initially prepared by dipping a 200 mesh copper grid (Formvar support film) in the sample solution, airdrying on filter paper, followed by TEM analysis.

\section{Preparation of stock solution of gold nanoparticles}

As per the previous report [21], Au-NPs were prepared by the citrate reduction method [22]. Gold(III) chloride tri-hydrate $(0.4768$ g) was added to $400 \mathrm{ml}$ of ultrapure water. The gold solution was then heated on a hotplate, $10 \mathrm{ml}$ of $0.2746 \mathrm{M}$ tri-sodium citrate was added to the boiling gold solution. The solution was stirred (300 rpm) and carefully observed for the color change, from yellow to colorless and finally to deep red. The red solution was immediately taken off the hotplate and allowed to cool to $25^{\circ} \mathrm{C}$. The Au-NP solution $(400 \mathrm{ml})$ was then transferred to a $2.0 \mathrm{~L}$ volumetric flask, and diluted with ultrapure water to volume. The solution was thoroughly mixed by inverting the flask for 20 times; no precipitate was observed. The Au-NPs were characterized by UV-Vis spectroscopy and TEM. 
Citation: Manickum T, John W, Toolsee N, Rajagopaul R (2015) Preliminary Performance Evaluation of the Gold Nanoparticle Method for Quantification of Residual Poly-(Diallyldimethyl Ammonium Chloride) in Treated Waters in the Umgeni Water Catchment, Kwazulu-Natal (South Africa). Hydrol Current Res 6: 206. doi:10.4172/2157-7587.1000206

Page 3 of 15

\section{Jar test procedure}

The purpose of Jar tests are used to predict clarification at water works. This method may be used to determine optimum dose of a polyelectrolyte for use as a primary coagulant and for comparing the performance of different polyelectrolytes. The Jar tests were performed at Wiggins Water Works, Umgeni Water. The standard procedure [23] is described in the Supplementary Material Text A. The optimum dose and most suitable coagulant for a particular site can be deduced from the Jar test results.

\section{Sample collection}

The four selected raw water sources (dams) (and respective water works (WW)) were: Inanda Dam (Wiggins WW), Nagle Dam (Durban Heights WW), Hazelmere Dam (Hazelmere WW) and Midmar Dam (DV Harris WW). Grab, raw water samples, and treated water samples, were collected from the designated water works sampling points that each dam supplies; each sample site has a unique sample point code. Samples were collected into $1 \mathrm{~L}$ plastic bottles, during the three-month study period: May, June and July 2014. The raw, potable (treated) water, and processed samples from the Jar Test procedure, were then submitted, in $1 \mathrm{~L}$ plastic bottles, to UKZN for subsequent analysis for poly-DADMAC. All collected and processed samples were assigned a unique identification number; the composition of the samples was not disclosed to the testing laboratory (UKZN) for the purpose of establishing accuracy and precision of the analytical method for residual poly-DADMAC

\section{Determination of poly-DADMAC by colorimetry-Au-NP}

Poly-DADMAC in the various water samples were analysed by the standard addition method [21]. The UV-Vis data obtained on each water sample was analysed by using three techniques: Absorbance of the peak at $690 \mathrm{~nm}$ (Method 1) (M1), Area of the peak at $690 \mathrm{~nm}$ (Method 2) (M2), and Ratio of the peak absorbances at $690 \mathrm{~nm}$ and 520 $\mathrm{nm}\left(\mathrm{A}_{690 \mathrm{~nm}} / \mathrm{A}_{520 \mathrm{~nm}}\right)$ (Method 3) (M3).

Calibration standards: All glassware was silanized before use. A $1.185 \mathrm{~g}$ sample of poly-DADMAC (35\% weight) was weighed into a vial (plastic) and transferred into a $1 \mathrm{~L}$ volumetric flask to make a $400 \mathrm{mg} / \mathrm{L}$ of poly-DADMAC stock solution. A $50 \mathrm{mg} / \mathrm{L}$ working stock solution of poly-DADMAC was prepared by transferring $12.5 \mathrm{ml}$ of poly-DADMAC stock solution $(400 \mathrm{mg} / \mathrm{L})$ into a $100 \mathrm{~mL}$ volumetric flask. All flasks were then diluted to volume with double distilled water. Three calibration standards: 0,10 and $20 \mu \mathrm{g} / \mathrm{L}$, in $50 \mathrm{ml}$ flasks, were used for Method 1 and Method 2; for Method 3, the 3 calibration standards were between $10-50 \mu \mathrm{g} / \mathrm{L}$.

Determination of poly-DADMAC by colorimetry-Au-NP: The real water samples were initially filtered through the $0.45 \mu \mathrm{m}$ GHP prefilter membrane. Approximately $25 \mathrm{ml}$ of ultrapure water (or water sample) was added into a $50 \mathrm{ml}$ volumetric flask. For the calibration standards, the required amount (e.g., $10 \mu \mathrm{L}$ for a $50 \mu \mathrm{g} / \mathrm{L}$ standard) of a $50 \mathrm{mg} / \mathrm{L}$ poly-DADMAC solution was added to the contents of the flask. A volume of $20 \mathrm{ml}$ of the Au-NP solution was then added to the flask. The blue solution was made up the $50 \mathrm{~mL}$ mark, mixed (by inverting the flask 20 times) and analyzed within 20 minutes. This was done to avoid the coagulant effect of poly-DADMAC.

\section{Statistical data analysis}

The comparison of observed poly-DADMAC levels for each sample determined by all three calibration methods were determined by oneway analysis of variance, and Bonferroni adjustment was performed afterwards to investigate significant pairwise differences. Tests for correlation and significance ( $p$-values less than 5\%) were determined using STATA12, by analysis of Scatter plots and determination of Pearson's correlation coefficient.

\section{Other Physico-chemical water quality data}

Other physico-chemical data, like TOC and turbidity, were, as required, obtained from the Umgeni Water Intranet, via the Labware Information Management System (LIMS).

\section{Results}

\section{Physico-chemical water quality}

After data analysis, the average turbidity, conductivity, TDS and TOC values are summarized in Table 1 . The raw data is appended in the Electronic Supplementary Material Table A, Figures A and B.

For the 3-month study period, the average raw water turbidity

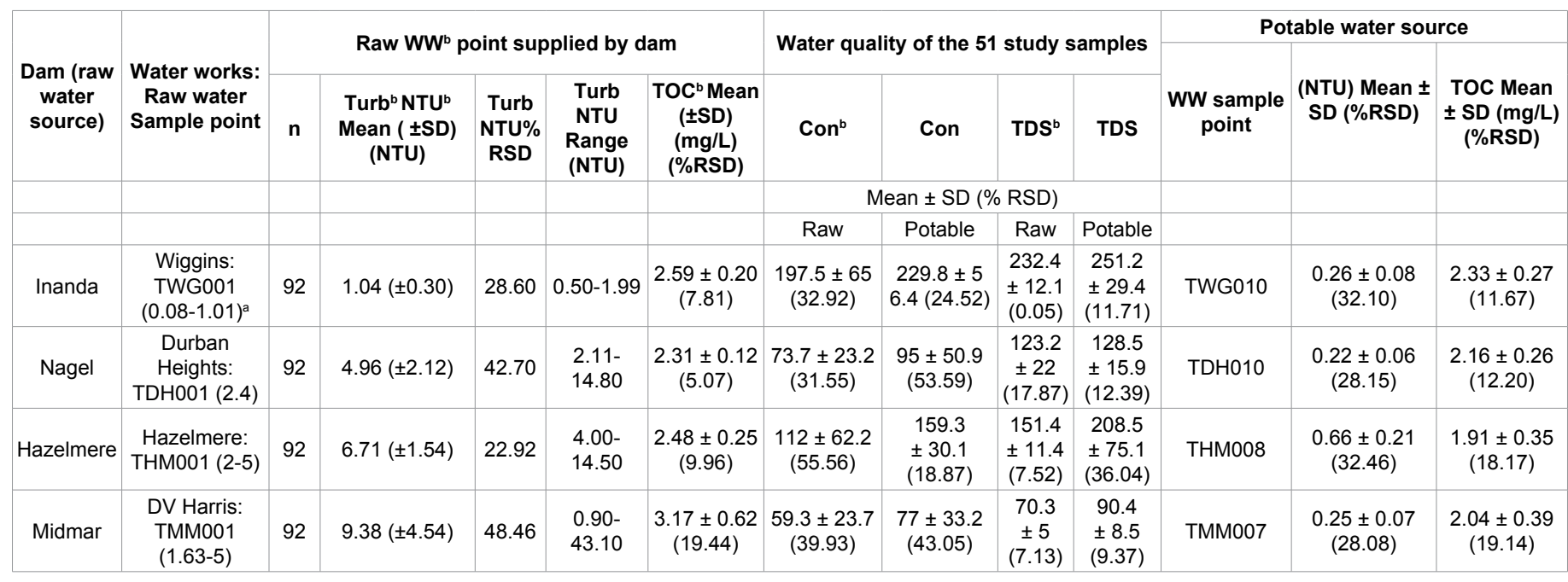

aCoagulant dosing level (mg/L)

${ }^{\text {b} C o n: ~ C o n d u c t i v i t y ; ~ T O C: ~ T o t a l ~ O r g a n i c ~ C a r b o n ; ~ T D S: ~ T o t a l ~ D i s s o l v e d ~ S o l i d s ; ~ T u r b: ~ T u r b i d i t y ; ~ N T U: ~ N e p h e l o m e t r i c ~ T u r b i d i t y ~ U n i t s ; ~ W W: ~ W a t e r ~ W o r k s . ~}$

Table 1: Physico-chemical water quality data. 
Citation: Manickum T, John W, Toolsee N, Rajagopaul R (2015) Preliminary Performance Evaluation of the Gold Nanoparticle Method for Quantification of Residual Poly-(Diallyldimethyl Ammonium Chloride) in Treated Waters in the Umgeni Water Catchment, Kwazulu-Natal (South Africa). Hydrol Current Res 6: 206. doi:10.4172/2157-7587.1000206

Page 4 of 15

(NTU) ( \pm Standard Deviation (SD)) was: $1.04( \pm 0.30)$ for Inanda, 4.936 $( \pm 2.12)$ for Nagle, $6.71( \pm 1.54)$ for Hazelmere and $9.38( \pm 4.54)$ for Midmar. For the conductivity, the average levels $(\mathrm{mS} / \mathrm{m})$ were: 59.3 $( \pm 23.7)$ for Midmar, $73.7( \pm 23.2)$ for Nagle, $112.0( \pm 62.2)$ for Hazelmere and $197.5( \pm 65)$ for Inanda. The average TDS levels $(\mathrm{mg} / \mathrm{L})$ were: 70.3 $( \pm 5)$ for Midmar, $123.2( \pm 22)$ for Nagle, $151.4( \pm 11.4)$ for Hazelmere and $232.4( \pm 12.1)$ for Inanda. The average TOC levels $(\mathrm{mg} / \mathrm{L})$ were: 2.31 $( \pm 0.12)$ for Nagle, $2.48( \pm 0.25)$ for Hazelmere, $2.59( \pm 0.2)$ for Inanda and $3.17( \pm 0.62)$ for Midmar. The overall Redox potential values $(\mathrm{mV})$ were $($ mean \pm SD) (median) (range): $-30 \pm(29)(-25)($ range $=+7$ to -80$)$ for all four dams. Individual average values were: $-41 \pm(49)(-41)(-76$ to -6$)$ for Midmar, $-32 \pm(43)(-25)$ ( -79 to 7$)$ for Hazelmere, $-25 \pm(1)$ (-25) (-25 to -24$)$ for Nagle, $-20 \pm(18)(-27)(-34$ to 12) for Inanda. The average values for $\mathrm{pH}$ were (mean $\pm \mathrm{SD}): 6.82( \pm 0.37)$ for Inanda, $7.09( \pm 0.16)$ for Nagle, $7.15( \pm 0.66)$ for Hazelmere and $7.17( \pm 0.6)$ for Midmar.
For the potable water, the average raw water turbidity (NTU) was: $0.22( \pm 0.06)$ for Nagle, $0.25( \pm 0.07)$ for Midmar, $0.26( \pm 0.08)$ for Inanda and $0.66( \pm 0.21)$ for Hazelmere. For conductivity, the average levels $(\mathrm{mS} / \mathrm{m})$ were: $77( \pm 33.2)$ for Midmar, $95.0( \pm 50.9)$ for Nagle, $159.3( \pm 30.1)$ for Hazelmere and $229.8( \pm 56.4)$ for Inanda. The average TDS levels $(\mathrm{mg} / \mathrm{L})$ were: $90.4( \pm 8.5)$ for Midmar, $128.5( \pm 15.9)$ for Nagle, $208.5( \pm 75.1)$ for Hazelmere and $251.2( \pm 29.4)$ for Inanda. The average TOC levels $(\mathrm{mg} / \mathrm{L})$ were: $1.91( \pm 0.35)$ for Hazelmere, $2.04( \pm$ $0.39)$ for Midmar, $2.16( \pm 0.26)$, for Nagle and $2.33( \pm 0.27)$ for Inanda. The overall Redox potential values $(\mathrm{mV})$ were $($ mean $\pm \mathrm{SD})$ (median) (range): $-14 \pm(12)(-11)$ (range $=-34$ to 2$)$ for all four dams. Individual values were: $-18 \pm(14)(-11)(-34$ to -11$)$ for Midmar, $-13 \pm(14)(-5)$ (-29 to -4$)$ for Hazelmere, $-11 \pm(15)(-5)(-29$ to 2) for Inanda, $-9 \pm$ (6) (-9) $(-13$ to -52$)$ for Nagle. The average values for $\mathrm{pH}$ were (mean \pm SD): $6.77( \pm 0.10)$ for Nagle, $6.79( \pm 0.22)$ for Inanda, $6.86( \pm 0.24)$ for Hazelmere and $6.94( \pm 0.20)$ for Midmar.

\begin{tabular}{|c|c|c|c|c|c|c|c|c|c|c|c|}
\hline \multirow{3}{*}{$\begin{array}{l}\text { Sample } \\
\qquad \text { ID }^{\mathrm{a}}\end{array}$} & \multirow{3}{*}{$\begin{array}{c}\text { Water works/ } \\
\text { Sample } \\
\text { description/ } \\
\text { Coagulant dose } \\
\text { concentration }\end{array}$} & \multirow{3}{*}{ Month } & \multicolumn{9}{|c|}{ Calibration method } \\
\hline & & & \multicolumn{2}{|c|}{$\begin{array}{c}\text { M1'a Peak absorbance @ } \\
690 \text { nm }\end{array}$} & \multicolumn{2}{|c|}{ M2 Peak area @ 690 nm } & \multicolumn{2}{|c|}{$\begin{array}{c}\text { M3 Ratio of peak } \\
\text { absorbances }\left(A_{690 \mathrm{~nm}} l\right. \\
\left.\mathrm{A}_{520 \mathrm{~nm}}\right)\end{array}$} & \multicolumn{3}{|c|}{ “M1 and M2" combined data } \\
\hline & & & $\begin{array}{l}\text { Observed } \\
\text { conc }^{\mathrm{a}}(\mu \mathrm{g} / \mathrm{L})\end{array}$ & $\begin{array}{l}\text { Observed } \% \\
\text { RSD }\end{array}$ & $\begin{array}{c}\text { Observed } \\
\text { conc }(\mu \mathrm{g} / \mathrm{L})\end{array}$ & $\begin{array}{c}\text { Observed } \% \\
\text { RSD }\end{array}$ & $\begin{array}{l}\text { Observed } \\
\text { conc }(\mu \mathrm{g} / \mathrm{L})\end{array}$ & $\begin{array}{l}\text { Observed } \% \\
\text { RSD }\end{array}$ & $\begin{array}{l}\text { Calculated } \\
\text { mean conc } \\
(\mu \mathrm{g} / \mathrm{L})\end{array}$ & $\begin{array}{l}\text { Calculated } \\
\text { SD }(\mu \mathrm{g} / \mathrm{L})\end{array}$ & $\begin{array}{c}\text { Calculated } \\
\% \text { RSD }\end{array}$ \\
\hline $4 \mathrm{R}$ & Wiggins: raw & May & 3.16 & 7.09 & 4.21 & 4.83 & 38.2 & 1.03 & 3.69 & 0.74 & 20.15 \\
\hline $5 \mathrm{R}$ & Wiggins: raw & May & 4.23 & 10.8 & 3.73 & 15.1 & $\mathrm{nd}^{\mathrm{a}}$ & 0.92 & 3.98 & 0.35 & 8.88 \\
\hline Mean & & & 3.70 & & 3.97 & & 38.20 & & & & \\
\hline SD & & & 0.76 & & 0.34 & & & & & & \\
\hline$\%$ RSD & & & 20.48 & & 8.55 & & & & & & \\
\hline $6 \mathrm{~F}$ & Wiggins: potable & May & 9.14 & 3.90 & 10.30 & 3.82 & 65.30 & 1.26 & 9.72 & 0.82 & 8.44 \\
\hline $7 \mathrm{~F}$ & Wiggins: potable & May & 1.38 & 2.35 & 1.11 & 26.10 & 64.60 & 1.76 & 1.25 & 0.19 & 15.33 \\
\hline $8 \mathrm{~F}$ & Wiggins: potable & May & 2.38 & 2.03 & 2.58 & 7.37 & 55.60 & 0.40 & 2.48 & 0.14 & 5.70 \\
\hline Mean & & & 4.30 & & 4.66 & & 61.83 & & & & \\
\hline SD & & & 4.22 & & 4.94 & & 5.41 & & & & \\
\hline$\%$ RSD & & & 98.17 & & 105.86 & & 8.75 & & & & \\
\hline $9 \mathrm{~B}$ & $\begin{array}{c}\text { Wiggins: raw: Jar } \\
\text { test }\end{array}$ & May & 12.70 & 6.62 & 11.00 & 6.46 & nd & 3.01 & 11.85 & 1.20 & 10.14 \\
\hline $10 \mathrm{~B}$ & $\begin{array}{c}\text { Wiggins: raw: Jar } \\
\text { test }\end{array}$ & May & 7.84 & 5.25 & 8.61 & 3.01 & 28.20 & 0.58 & 8.23 & 0.54 & 6.62 \\
\hline Mean & & & 10.27 & & 9.81 & & 28.20 & & & & \\
\hline SD & & & 3.44 & & 1.69 & & & & & & \\
\hline$\%$ RSD & & & 33.46 & & 17.24 & & & & & & \\
\hline 110 & $\begin{array}{l}\text { Wiggins raw: Jar } \\
\text { test: optimal dose }\end{array}$ & May & 22.70 & 7.86 & 21.30 & 7.34 & nd & 3.61 & 22.00 & 0.99 & 4.50 \\
\hline 120 & $\begin{array}{l}\text { Wiggins raw: Jar } \\
\text { test: optimal dose }\end{array}$ & May & 17.21 & & & & & & 17.21 & & \\
\hline 130 & $\begin{array}{l}\text { Wiggins/ optimal } \\
\text { dose }\end{array}$ & May & 14.10 & 3.01 & 19.10 & 1.50 & nd & 3.01 & 16.60 & 3.54 & 21.30 \\
\hline Mean & & & 18.00 & & 20.20 & & & 3.31 & & & \\
\hline $\mathrm{SD}$ & & & 4.35 & & 1.56 & & & 0.42 & & & \\
\hline$\%$ RSD & & & 24.19 & & 7.70 & & & 12.82 & & & \\
\hline 14 & $\begin{array}{l}\text { Wiggins raw: Jar } \\
\text { test; } 30 \% \text { overdose }\end{array}$ & May & 1.90 & & & & & & 1.90 & & \\
\hline 15 & $\begin{array}{l}\text { Wiggins raw: Jar } \\
\text { test: } 60 \% \text { overdose }\end{array}$ & May & 0.29 & 16.00 & 0.47 & 31.30 & 54.30 & 0.37 & 0.38 & 0.12 & 32.92 \\
\hline 16 & $\begin{array}{l}\text { Wiggins raw: } \\
\text { Jar test: } 100 \% \\
\text { overdose }\end{array}$ & May & 2.79 & 11.70 & 4.17 & 21.70 & nd & 2.39 & 3.48 & 0.98 & 28.04 \\
\hline $20 \mathrm{R}$ & Wiggins: raw & June & 3.60 & 4.34 & 4.11 & 9.75 & 48.20 & 0.98 & 3.86 & 0.36 & 9.35 \\
\hline $20 \mathrm{~F}$ & Wiggins: potable & June & 0.713 & 3.39 & 1.53 & 2.04 & 15.3 & 0.38 & 1.12 & 0.58 & 51.51 \\
\hline 21B & $\begin{array}{l}\text { Wiggins: raw: Jar } \\
\text { test }\end{array}$ & June & 5.12 & 12.60 & 5.59 & 5.60 & 40.50 & 3.45 & 5.36 & 0.33 & 6.21 \\
\hline 22B & $\begin{array}{c}\text { Wiggins: raw: Jar } \\
\text { test }\end{array}$ & June & 1.49 & 4.90 & 1.95 & 5.20 & 22.70 & 0.17 & 1.72 & 0.33 & 18.91 \\
\hline
\end{tabular}


Citation: Manickum T, John W, Toolsee N, Rajagopaul R (2015) Preliminary Performance Evaluation of the Gold Nanoparticle Method for Quantification of Residual Poly-(Diallyldimethyl Ammonium Chloride) in Treated Waters in the Umgeni Water Catchment, Kwazulu-Natal (South Africa). Hydrol Current Res 6: 206. doi:10.4172/2157-7587.1000206

Page 5 of 15

\begin{tabular}{|c|c|c|c|c|c|c|c|c|c|c|c|}
\hline Mean & & & 3.31 & & 3.77 & 5.40 & 31.60 & & & & \\
\hline SD & & & 2.57 & & 2.57 & 0.28 & 12.59 & & & & \\
\hline \%RSD & & & 77.66 & & 68.27 & 5.24 & 39.83 & & & & \\
\hline 230 & $\begin{array}{l}\text { Wiggins: raw: Jar } \\
\text { test: optimal }\end{array}$ & June & 0.53 & 8.90 & 0.64 & 15.00 & 13.20 & 0.44 & 0.58 & 0.08 & 14.15 \\
\hline 24 & $\begin{array}{l}\text { Wiggins: raw: Jar } \\
\text { test: } 30 \% \text { overdose }\end{array}$ & June & 3.64 & 8.10 & 4.41 & 2.72 & 42.80 & 1.01 & 4.03 & 0.54 & 13.53 \\
\hline 25 & $\begin{array}{l}\text { Wiggins: raw: Jar } \\
\text { test: } 30 \% \text { overdose }\end{array}$ & June & 4.77 & 1.20 & 5.88 & 1.17 & 47.30 & 0.65 & 5.33 & 0.78 & 14.74 \\
\hline 26 & $\begin{array}{l}\text { Wiggins: raw: Jar } \\
\text { test: } 30 \% \text { overdose }\end{array}$ & June & 1.78 & 5.09 & 2.16 & 8.85 & 30.90 & 5.46 & 1.97 & 0.27 & 13.64 \\
\hline Mean & & & 3.40 & & 4.15 & 4.25 & 40.33 & & & & \\
\hline SD & & & 1.51 & & 1.87 & 4.06 & 8.47 & & & & \\
\hline$\%$ RSD & & & 44.45 & & 45.15 & 95.63 & 21.01 & & & & \\
\hline 27 & $\begin{array}{l}\text { Wiggins: raw: Jar } \\
\text { test: } 60 \% \text { overdose }\end{array}$ & June & 5.65 & 0.48 & 7.35 & 0.07 & 35.60 & 0.50 & 6.50 & 1.20 & 18.49 \\
\hline 28 & $\begin{array}{c}\text { Wiggins: raw: } \\
\text { Jar test: } 100 \% \\
\text { overdose }\end{array}$ & June & 1.61 & 5.82 & 0.72 & 1.70 & 11.90 & 1.03 & 1.17 & 0.63 & 53.77 \\
\hline $32 R$ & & July & 3.93 & 7.19 & 4.00 & 7.57 & 47.20 & 0.97 & 3.97 & 0.05 & 1.25 \\
\hline $32 \mathrm{~F}$ & & July & 1.27 & 4.27 & 1.80 & 0.22 & 9.44 & 0.73 & 1.54 & 0.37 & 24.41 \\
\hline $33 \mathrm{~B}$ & $\begin{array}{c}\text { Wiggins: raw: Jar } \\
\text { test }\end{array}$ & July & 5.51 & 0.63 & 7.21 & 1.79 & 54.20 & 0.80 & 6.36 & 1.20 & 18.90 \\
\hline $34 \mathrm{~B}$ & $\begin{array}{l}\text { Wiggins: raw: Jar } \\
\text { test }\end{array}$ & July & 12.90 & 4.84 & 12.00 & 7.20 & 44.10 & 2.73 & 12.45 & 0.64 & 5.11 \\
\hline Mean & & & 9.21 & & 9.61 & & 49.15 & & & & \\
\hline SD & & & 5.23 & & 3.39 & & 7.14 & & & & \\
\hline$\%$ RSD & & & 56.77 & & 35.26 & & 14.53 & & & & \\
\hline 350 & Wiggins optimal & July & 1.08 & 8.09 & 0.41 & 19.50 & 7.85 & 1.12 & 0.75 & 0.47 & 63.32 \\
\hline 36 & $\begin{array}{c}\text { Wiggins } 30 \% \\
\text { overdose }\end{array}$ & July & 1.12 & 4.15 & 1.19 & 24.40 & 6.44 & 1.89 & 1.16 & 0.05 & 4.29 \\
\hline 37 & $\begin{array}{l}\text { Wiggins } 60 \% \\
\text { overdose }\end{array}$ & July & 2.48 & 2.51 & 3.53 & 1.24 & 9.58 & 0.39 & 3.01 & 0.74 & 24.71 \\
\hline 38 & $\begin{array}{l}\text { Wiggins } 60 \% \\
\text { overdose }\end{array}$ & July & 0.19 & 12.00 & 0.74 & 4.01 & 9.71 & 0.17 & 0.46 & 0.39 & 83.45 \\
\hline 39 & $\begin{array}{l}\text { Wiggins } 60 \% \\
\text { overdose }\end{array}$ & July & 3.11 & 4.46 & 5.18 & 2.99 & 8.03 & 1.20 & 4.15 & 1.46 & 35.31 \\
\hline Mean & & & 1.93 & & 3.15 & & 9.11 & & & & \\
\hline SD & & & 1.54 & & 2.25 & & 0.93 & & & & \\
\hline$\%$ RSD & & & 79.76 & & 71.32 & & 10.26 & & & & \\
\hline 40 & $\begin{array}{l}\text { Wiggins } 100 \% \\
\text { overdose }\end{array}$ & July & 2.70 & 2.52 & 2.16 & 6.52 & 10.20 & 1.26 & 2.43 & 0.38 & 15.71 \\
\hline $1 \mathrm{R}$ & DV Harris: raw & May & 6.79 & 7.15 & 6.61 & 7.72 & nd & 2.08 & 6.70 & 0.13 & 1.90 \\
\hline $1 \mathrm{~F}$ & DV Harris: potable & May & 1.85 & 8.84 & 2.34 & 12.00 & 17.20 & 0.95 & 2.10 & 0.35 & 16.54 \\
\hline $17 R$ & DV Harris: raw & June & 5.48 & 2.93 & 8.14 & 0.79 & 5.32 & 2.39 & 6.81 & 1.88 & 27.62 \\
\hline $17 \mathrm{~F}$ & DV Harris: potable & June & 0.99 & 33.00 & 2.71 & 2.43 & 12.20 & 0.28 & 1.85 & 1.22 & 65.85 \\
\hline $29 R$ & DV Harris: raw & July & 18.10 & 9.70 & 18.90 & 8.92 & 62.00 & 6.20 & 18.50 & 0.57 & 3.06 \\
\hline $29 \mathrm{~F}$ & DV Harris: potable & July & 0.82 & 5.52 & 0.40 & 6.57 & 13.40 & 0.40 & 0.61 & 0.30 & 49.07 \\
\hline $2 \mathrm{R}$ & Hazelmere: raw & May & 1.43 & 2.06 & 2.30 & 0.41 & 23.30 & 0.33 & 1.87 & 0.62 & 32.99 \\
\hline $2 \mathrm{~F}$ & Hazelmere: potable & May & 2.70 & 7.91 & 4.20 & 7.67 & 15.80 & 1.36 & 3.45 & 1.06 & 30.74 \\
\hline $18 \mathrm{R}$ & Hazelmere: raw & June & 17.25 & 0.95 & 23.80 & 0.69 & 52.20 & 0.83 & 20.53 & 4.63 & 22.57 \\
\hline $18 \mathrm{~F}$ & Hazelmere potable & June & 0.22 & 34.10 & 0.67 & 16.50 & 10.70 & 0.40 & 0.44 & 0.31 & 70.79 \\
\hline $30 \mathrm{R}$ & Hazelmere: raw & July & 1.78 & 4.33 & 2.31 & 0.65 & 16.80 & 0.69 & 2.05 & 0.37 & 18.33 \\
\hline $30 \mathrm{~F}$ & Hazelmere: potable & July & 0.72 & 5.33 & 1.25 & 4.99 & 8.50 & 0.47 & 0.98 & 0.38 & 38.23 \\
\hline $3 R$ & $\begin{array}{c}\text { Durban Heights: } \\
\text { raw }\end{array}$ & May & 13.30 & 4.70 & 13.40 & 6.36 & nd & 0.31 & 13.35 & 0.07 & 0.53 \\
\hline $3 F$ & $\begin{array}{l}\text { Durban Heights: } \\
\text { potable }\end{array}$ & May & 2.01 & 23.80 & 2.87 & 15.10 & 57.00 & 2.12 & 2.44 & 0.61 & 24.92 \\
\hline $19 \mathrm{R}$ & $\begin{array}{c}\text { Durban Heights: } \\
\text { potable }\end{array}$ & June & 2.36 & 12.70 & 3.50 & 11.70 & 16.50 & 1.65 & 2.93 & 0.81 & 27.51 \\
\hline $19 \mathrm{~F}$ & $\begin{array}{c}\text { Durban Heights: } \\
\text { potable }\end{array}$ & June & 0.89 & 8.68 & 0.95 & 9.66 & 13.80 & 0.40 & 0.92 & 0.04 & 4.61 \\
\hline $31 R$ & $\begin{array}{c}\text { Durban Heights: } \\
\text { raw }\end{array}$ & July & 1.54 & 4.33 & 2.31 & 0.65 & 16.80 & 0.69 & 1.93 & 0.54 & 28.28 \\
\hline $31 \mathrm{~F}$ & $\begin{array}{l}\text { Durban Heights: } \\
\text { potable }\end{array}$ & July & 8.02 & 1.54 & 11.20 & 0.99 & 26.00 & 0.29 & 9.61 & 2.25 & 23.40 \\
\hline
\end{tabular}

aconc.: Concentration; ID: Identity; nd: Not Detected.

Table 2: The observed levels of poly-DADMAC for all the samples. 
Citation: Manickum T, John W, Toolsee N, Rajagopaul R (2015) Preliminary Performance Evaluation of the Gold Nanoparticle Method for Quantification of Residual Poly-(Diallyldimethyl Ammonium Chloride) in Treated Waters in the Umgeni Water Catchment, Kwazulu-Natal (South Africa). Hydrol Current Res 6: 206. doi:10.4172/2157-7587.1000206

Page 6 of 15

\begin{tabular}{|c|c|c|c|c|c|c|c|c|c|c|c|c|c|c|}
\hline \multirow{4}{*}{$\begin{array}{c}\text { Water } \\
\text { works/ } \\
\text { dam }\end{array}$} & \multirow{4}{*}{ Coag. $^{a}$} & \multirow{4}{*}{$\begin{array}{l}\text { Dosing } \\
\text { level: } \\
\text { May-July } \\
\text { (mg/L) }\end{array}$} & \multirow{4}{*}{$\mathbf{n}$} & \multicolumn{9}{|c|}{ Poly-DADMAC concentration $(\mu \mathrm{g} / \mathrm{L})$} & \multirow{4}{*}{$\begin{array}{c}\text { Mean } \\
\text { M3/M1 }\end{array}$} & \multirow{4}{*}{$\begin{array}{c}\text { Mean M3/ } \\
\text { M2 }\end{array}$} \\
\hline & & & & \multirow{2}{*}{\multicolumn{2}{|c|}{ Method 1 (M1) }} & \multicolumn{4}{|c|}{ Calibration technique } & & & \\
\hline & & & & & & \multicolumn{2}{|c|}{ Method 2 (M2) } & \multicolumn{2}{|c|}{ Method 3 (M3) } & \multicolumn{3}{|c|}{ Redox potential (mV) } & & \\
\hline & & & & Mean \pm SD & $\%$ RSD & Mean \pm SD & \%RSD & Mean \pm SD & \%RSD & Mean \pm SD & Median & Range & & \\
\hline \multicolumn{15}{|c|}{ Raw water } \\
\hline $\begin{array}{l}\text { Wiggins/ } \\
\text { Inanda }\end{array}$ & & & 4 & $3.73 \pm 0.46$ & 12.30 & $4.01 \pm 0.21$ & 5.16 & $44.53 \pm 5.51$ & 12.37 & $-20 \pm(18)$ & -27 & -34 to +12 & 11.9 & 11.1 \\
\hline $\begin{array}{l}\text { DV Harris/ } \\
\text { Midmar }\end{array}$ & & & 3 & $10.12 \pm 6.94$ & 68.54 & $11.22 \pm 6.70$ & 59.71 & $33.66 \pm 40.08$ & 119.07 & $-41 \pm(49)$ & -41 & -76 to -6 & 3.3 & 3.0 \\
\hline $\begin{array}{l}\text { Hazelmere/ } \\
\text { Hazelmere }\end{array}$ & & & 3 & $6.82 \pm 9.03$ & 132.47 & $9.47 \pm 12.41$ & 131.05 & $30.77 \pm 18.84$ & 61.25 & $-32 \pm(43)$ & -25 & -79 to +7 & 4.5 & 3.2 \\
\hline $\begin{array}{c}\text { Durban } \\
\text { Heights/ } \\
\text { Nagel }\end{array}$ & & & 3 & $5.73 \pm 6.57$ & 114.52 & $6.40 \pm 6.09$ & 95.08 & $16.65 \pm 0.21$ & 1.27 & $-25 \pm(1)$ & -25 & -25 to -24 & 2.9 & 2.6 \\
\hline \multicolumn{15}{|c|}{ Potable water } \\
\hline $\begin{array}{l}\text { Wiggins/ } \\
\text { Inanda }\end{array}$ & Z553D & $0.08-1.01$ & 4 & $3.40 \pm 3.89$ & 114.21 & $3.88 \pm 4.32$ & 111.45 & $50.20 \pm 23.68$ & 47.18 & $-11 \pm(15)$ & -5 & -29 to 1 & 14.8 & 12.9 \\
\hline $\begin{array}{l}\text { DV Harris/ } \\
\text { Midmar }\end{array}$ & Z553D & $1.63-5$ & 3 & $1.22 \pm 0.55$ & 45.19 & $1.82 \pm 1.24$ & 68.34 & $14.27 \pm 2.61$ & 18.30 & $-18(14)$ & -11 & -34 to -10 & 11.7 & 7.8 \\
\hline $\begin{array}{c}\text { Hazelmere/ } \\
\text { Hazelmere }\end{array}$ & SF3456 & $2-5$ & 3 & $1.21 \pm 1.31$ & 108.06 & $2.04 \pm 1.89$ & 92.89 & $11.67 \pm 3.74$ & 32.10 & $-13 \pm(14)$ & -5 & -29 to -4 & 9.6 & 5.7 \\
\hline $\begin{array}{c}\text { Durban } \\
\text { Heights/ } \\
\text { Nagle }\end{array}$ & SF3435 & 2.4 & 3 & $3.64 \pm 3.83$ & 105.36 & $5.01 \pm 5.45$ & 108.89 & $32.27 \pm 22.27$ & 69.02 & $-9 \pm(6)$ & -9 & -13 to -5 & 8.9 & 6.4 \\
\hline
\end{tabular}

Table 3: The computed mean residual poly-DADMAC values for the raw dam waters and corresponding potable water samples.

\section{Poly-DADMAC levels on raw and potable water}

The observed levels of poly-DADMAC for all water samples is listed in Table 2; computed averages for the four raw dam water and associated potable waters are listed in Table 3 (Supplementary Figure A). The observed, residual poly-DADMAC levels, obtained by Method 1, (range: $6-16 \mu \mathrm{g} / \mathrm{L})$ were, on average $( \pm \mathrm{SD})(\mu \mathrm{g} / \mathrm{L})$, for the raw water samples: $3.73( \pm 0.46)$ for Inanda Dam, $5.73( \pm 6.57)$ for Nagle Dam, 6.82 $( \pm 9.03)$ for Hazelmere Dam, and $10.12( \pm 6.94)$ for Midmar Dam (Table 3 ). The corresponding potable water levels (range: $<2-8 \mu \mathrm{g} / \mathrm{L}$ ), were: on average $( \pm \mathrm{SD})(\mu \mathrm{g} / \mathrm{L}), 1.21( \pm 1.31)$ for Hazelmere Dam, $1.22( \pm 0.55)$ for Midmar Dam, $3.40( \pm 3.89)$ for Inanda Dam, and $3.64( \pm 3.83)$ for Nagle Dam. The observed, residual poly-DADMAC levels, obtained by Method 2, (range: $0-22 \mu \mathrm{g} / \mathrm{L})$ were, on average $( \pm \mathrm{SD})(\mu \mathrm{g} / \mathrm{L})$, for the raw water samples: $4.01( \pm 0.21)$ for Inanda Dam, $6.40( \pm 6.09)$ for Nagle Dam, $9.47( \pm 12.41)$ for Hazelmere Dam, and $11.22( \pm 6.70)$ for Midmar Dam. The corresponding potable water levels (range: $<2-11 \mu \mathrm{g} / \mathrm{L}$ ), were: on average $( \pm \mathrm{SD})(\mu \mathrm{g} / \mathrm{L}), 1.82( \pm 1.24)$ for Midmar Dam, $2.04( \pm 1.89)$ for Hazelmere Dam, $3.88( \pm 4.32)$ for Inanda Dam, and $5.01( \pm 5.45)$ for Nagle Dam. The observed, residual poly-DADMAC levels, obtained by Method 3, (range: $16.65-44.53 \mu \mathrm{g} / \mathrm{L})$ were, on average $( \pm \mathrm{SD})(\mu \mathrm{g} / \mathrm{L})$, for the raw water samples: $16.65 \pm 0.21$ for Nagle dam, $30.77 \pm 18.84$ for Hazelmere Dam, $33.66 \pm 40.08$ for Midmar Dam and $44.53 \pm 5.51$ for Inanda Dam. The corresponding potable water levels, (range: 16.65$44.53 \mu \mathrm{g} / \mathrm{L})$ were, on average $( \pm \mathrm{SD})(\mu \mathrm{g} / \mathrm{L})$, for the raw water samples: $11.67 \pm 3.74$ for Hazelmere Dam, $14.27 \pm 2.61$ for Midmar Dam, 32.27 \pm 22.27 for Nagle dam, and $50.20 \pm 23.68$ for Inanda Dam.

\section{Discussion}

\section{Physicochemical water quality}

Raw dam water: For the 3-month study period, the average raw water turbidity increases in the order: Inanda (1.04) $<$ Nagle $<$ Hazelmere $<$ Midmar Dam (9.38). For the raw water turbidity, the data indicates the lowest average value of 1 NTU for Inanda Dam, which is very much lower than that of the other three raw dam waters ( 5 for Nagle and 9 NTU for Midmar dam). The national drinking water guide limit, as per the South African National Standards (SANS) 241: 2011, for turbidity is $1 \mathrm{NTU}$, and the Umgeni Water internal limit for potable water is lower, at $\leq 0.5 \mathrm{NTU}$. In general, very turbid waters will be expected to require a higher concentration of coagulant for flocculation during the water treatment process. This requirement is confirmed in the increasing dosage of poly-DADMAC that was used at the respective raw water treatment plants: the lowest dose being $0.08-1.01 \mathrm{mg} / \mathrm{L}$, for Inanda Dam (1 NTU), up to a maximum 1.63-5 mg/L, for Midmar Dam (9 NTU). There is minimal difference in $\mathrm{pH}$, which ranges from 6.8 for Inanda, to 7.2 for Midmar. These values do comply with the national SANS 241 limit of $\geq 5$ to $\leq 9.7$. The average conductivity and TDS levels increase in the order: Midmar $<$ Nagle $<$ Hazelmere $<$ Inanda. Except for Inanda, all other three dam levels comply with the national SANS 241: 2011 potable water limit of $\leq 170 \mathrm{mS} / \mathrm{m}$ for conductivity, and $\leq 1200$ $\mathrm{mg} / \mathrm{L}$ for TDS. It is also evident that the coagulant blends, containing poly-DADMAC, function effectively as organic, polymeric flocculants, in lowering the raw water turbidity, from 5-9 NTU to the national limit of $\leq 1$, for all four raw dam waters. The average TOC levels increase in the order: Nagle $<$ Hazelmere $<$ Inanda $<$ Midmar. However, levels for all four dams comply with the national potable water guide (SANS 241: 2011) limit of $\leq 10 \mathrm{mg} / \mathrm{L}$.

Potable water: The potable water turbidity values (NTU), much lower than the raw waters, indicate fairly good similarity for the three dams: Midmar (0.22), Nagle (0.25), and Inanda Dam (0.26), whilst that for Hazelmere is approximately three times higher $(0.66 \mathrm{NTU})$. However, all values do comply with the national SANS 241: 2011 potable water quality limit of being $\leq 1 \mathrm{NTU}$. The average conductivity and TDS levels increase in the order: Midmar $<$ Nagle $<$ Hazelmere $<$ Inanda. Except for Inanda $(230 \mathrm{mS} / \mathrm{m})$, all other three dam levels comply with the national SANS 241 potable water limit of $\leq 170 \mathrm{mS} / \mathrm{m}$ for conductivity, and $\leq 1200 \mathrm{mg} / \mathrm{L}$ for TDS. For all four dams, the conductivity and TDS levels on the treated (potable) water exceed that for the corresponding raw dam water. Whilst there is no significant difference in TOC levels for all four dams, there is a noticeable lower TOC content in all the potable waters compared to the corresponding raw dam water. 
Citation: Manickum T, John W, Toolsee N, Rajagopaul R (2015) Preliminary Performance Evaluation of the Gold Nanoparticle Method for Quantification of Residual Poly-(Diallyldimethyl Ammonium Chloride) in Treated Waters in the Umgeni Water Catchment, Kwazulu-Natal (South Africa). Hydrol Current Res 6: 206. doi:10.4172/2157-7587.1000206

Page 7 of 15

\section{Method validation for the poly-DADMAC assay method}

Detailed data has been previously reported [21]. The linearity range was between 0 and $30 \mu \mathrm{g} / \mathrm{L}$ with $\mathrm{r}^{2}=0.99$ in all cases. The method LOD and LOQ $(\mu \mathrm{g} / \mathrm{L}$ ) was 0.49 and 1.47 for Method 1 (absorbance of peak at $690 \mathrm{~nm}$ ), 0.31 and 0.94 for Method 2 (area of peak at $690 \mathrm{~nm}$ ) and 0.54 and 1.64 for Method 3 (ratio of the absorbance of peaks at 690 and $520 \mathrm{~nm}\left(\mathrm{~A}_{690 \mathrm{~nm}} / \mathrm{A}_{520 \mathrm{~nm}}\right)$. From the raw data supplied (Supplementary Material Text $B)$, the computed instrument precision (\% RSD) $( \pm S D)$, based on signal response, was: $18.05( \pm 17.65)$ for Method $1,18.81$ $( \pm 18.44)$ for Method 2, and $3.24( \pm 3.23)$ for Method 3. The overall mean within-batch (repeatability) precision (\%RSD) for the triplicate assay values were: $7.42( \pm 7.07)$ for Method 1, $7.66( \pm 7.37)$ for Method 2 , and $1.92( \pm 2.71)$ for Method 3. The overall mean between-batch (reproducibility)\%RSD was: $54.37( \pm 30.03)$ for Method 1, 35.89 $( \pm 34.89)$ for Method 2 and $13.50( \pm 12.64)$ for Method 3.

\section{Observed residual levels of poly-DADMAC in all water samples}

Raw dam water samples: Typical calibration graphs are shown in Figure 1 (Method 1: absorbance of peak at $690 \mathrm{~nm}$ ), Figure 2 (Method 3: area of peak at $690 \mathrm{~nm}$ ), and Figure 3 (Method 3: ratio of peak absorbances at $690 \mathrm{~nm}$ and $520 \mathrm{~nm}$ ). The observed levels of poly-DADMAC for all the samples by all three calibration Methods 1,2 and 3, are listed in Table 2 (Supplementary Figures C and D). After data processing, the observed mean values $( \pm$ SD) (Table 3 ) were $(\mu \mathrm{g} / \mathrm{L})$, by Method 1, 2, and 3: $3.73( \pm 0.46), 4.01( \pm 0.21), 44.53$ $( \pm 5.51)$ for Wiggins WW, $10.12( \pm 6.94), 11.22( \pm 6.70), 33.66( \pm 40.08)$ for DV Harris WW, $6.82( \pm 9.03), 9.47( \pm 12.41), 30.77( \pm 18.84)$ for
Hazelmere WW, $5.73( \pm 6.57), 6.40( \pm 6.09), 16.65( \pm 0.21)$ for Durban Heights WW. The typical UV-Vis spectra, for sample 4R (Wiggins WW: May), with the calibration standards, is shown in Figure 4. For assay values obtained by Methods 1 and 2, the poly-DADMAC levels, in the four dams, increase in the following order: Inanda $<$ Nagle $<$ Hazelmere $<$ Midmar. However, for values obtained by Method 3 , the order is: Nagle $<$ Hazelmere $<$ Midmar $<$ Inanda.

Potable (treated) water samples: The observed levels of polyDADMAC for all samples are listed in Table 2. After data analysis, the observed mean values $( \pm \mathrm{SD})$ (Table 3 ) were $(\mu \mathrm{g} / \mathrm{L})$, by Method 1 , 2, and 3: $3.40( \pm 3.89), 3.88( \pm 4.32), 50.20( \pm 23.68)$ for Wiggins WW, $1.22( \pm 0.55), 1.82( \pm 1.24), 12.27( \pm 6.21)$ for DV Harris WW, 1.21 ( \pm 1.31$), 2.04( \pm 1.89), 11.67( \pm 3.74)$ for Hazelmere WW, $3.64( \pm 3.83)$, $5.01( \pm 5.45), 32.27( \pm 22.27)$ for Durban Heights WW (Table 3). The typical UV-Vis spectra, for sample 6F (Wiggin's potable: May), with the calibration standards, is shown in Figure 5.

For assay values obtained by Methods 1 and 2, the poly-DADMAC levels, for the four dams, increase in the following order: Midmar/ Hazelmere $<$ Inanda $<$ Nagle. However, for values obtained by Method 3, the order is: Hazelmere $<$ Midmar $<$ Nagle $<$ Inanda.

\section{Determination of the UV-Vis spectra}

The UV-Data were recorded once only; different mathematical models are applied to calculate the concentration. This one set of UVdata was then used in the 1 models (absorbance, area and ratio). The calibration was obtained using three techniques. The first approach involves plotting peak absorbance at $690 \mathrm{~nm}$ (corresponds to the

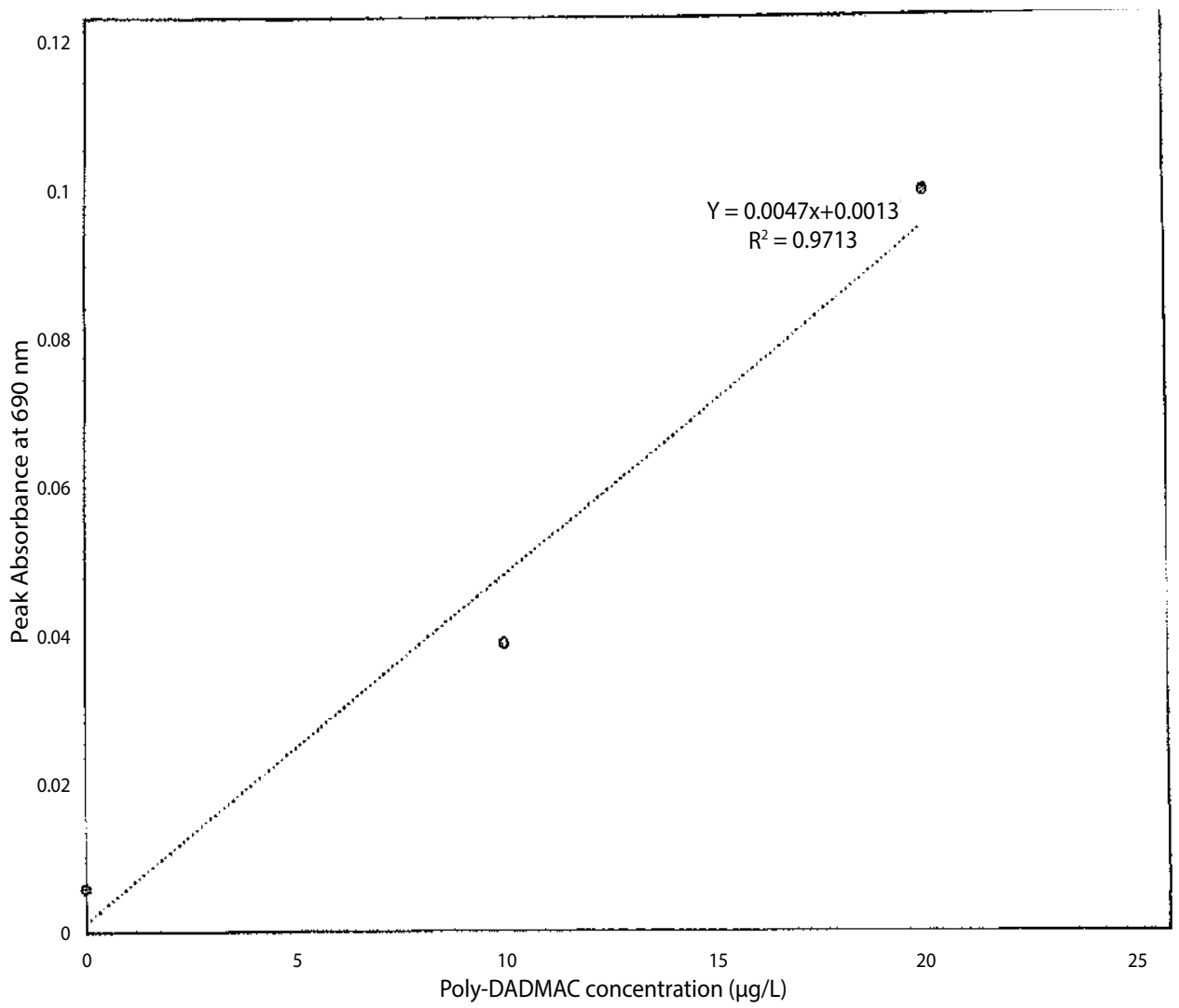

Figure 1: Calibration graph for raw dam water sample $4 R$ by the peak absorbance Method 1 . 
Citation: Manickum T, John W, Toolsee N, Rajagopaul R (2015) Preliminary Performance Evaluation of the Gold Nanoparticle Method for Quantification of Residual Poly-(Diallyldimethyl Ammonium Chloride) in Treated Waters in the Umgeni Water Catchment, Kwazulu-Natal (South Africa). Hydrol Current Res 6: 206. doi:10.4172/2157-7587.1000206

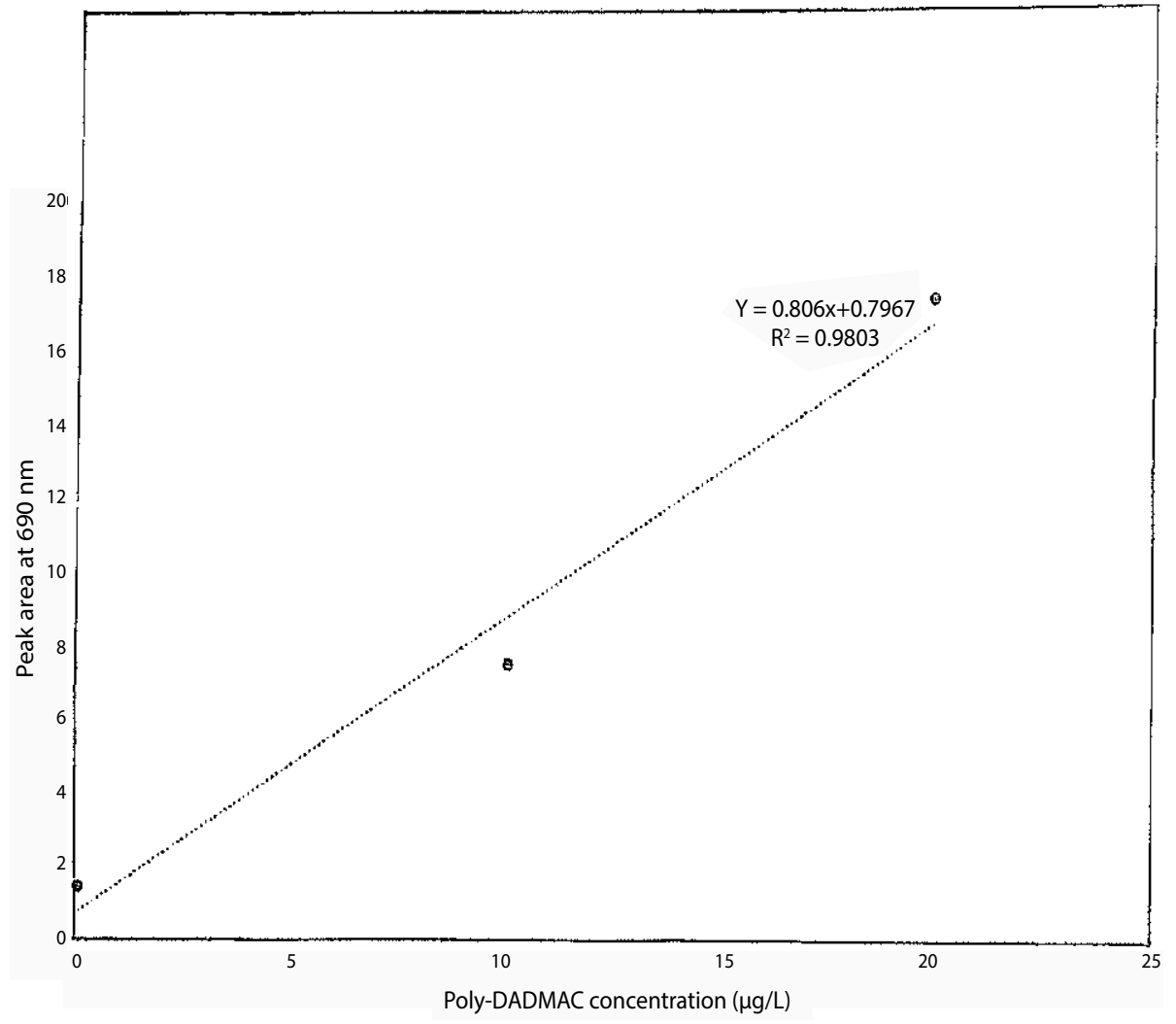

Figure 2: Calibration graph for raw dam water sample 4R by the peak area Method 2.

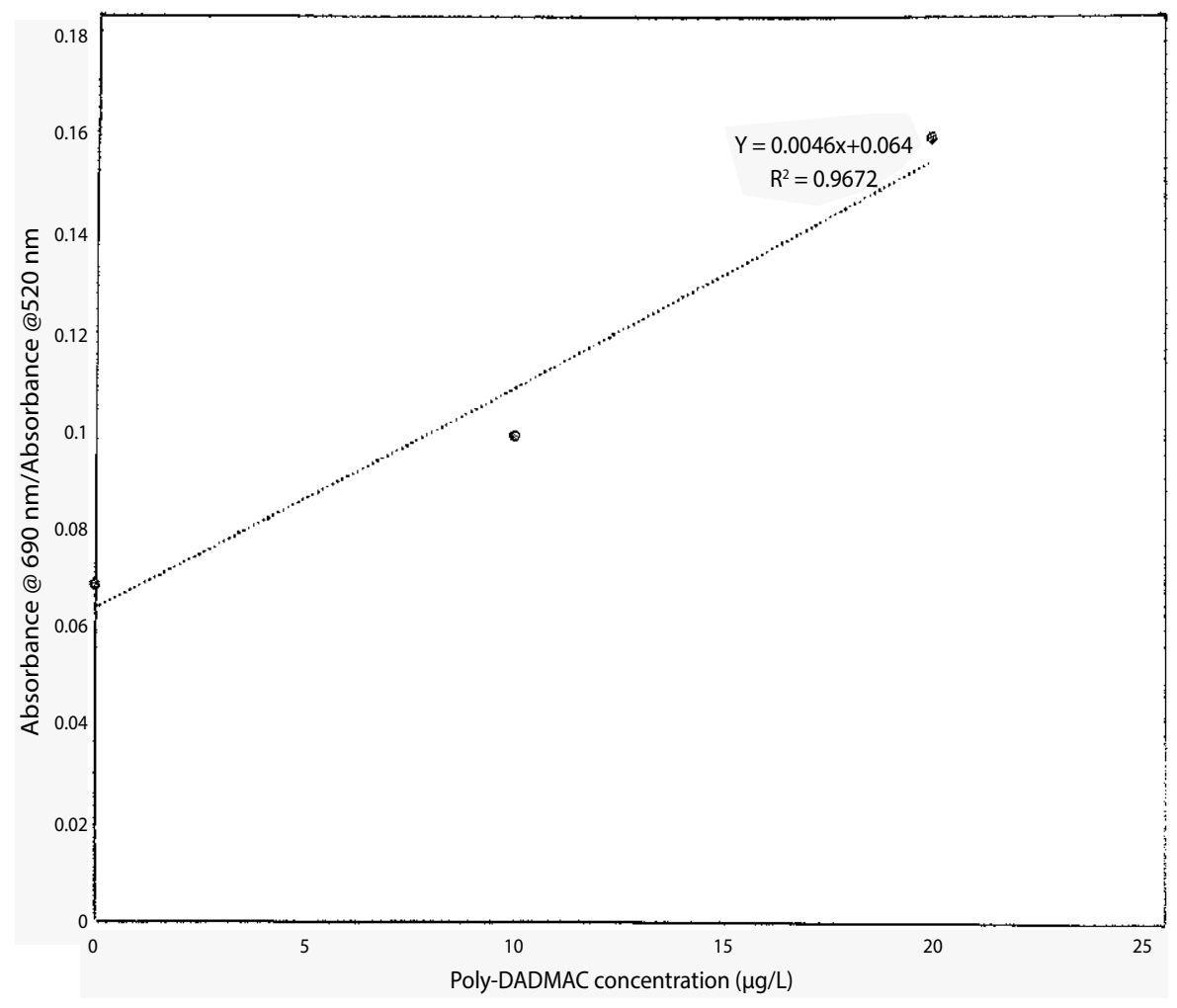

Figure 3: Calibration graph for raw dam water sample $4 R$ by the ratio Method 3 . 

of Residual Poly-(Diallyldimethyl Ammonium Chloride) in Treated Waters in the Umgeni Water Catchment, Kwazulu-Natal (South Africa). Hydrol Current Res 6: 206. doi:10.4172/2157-7587.1000206

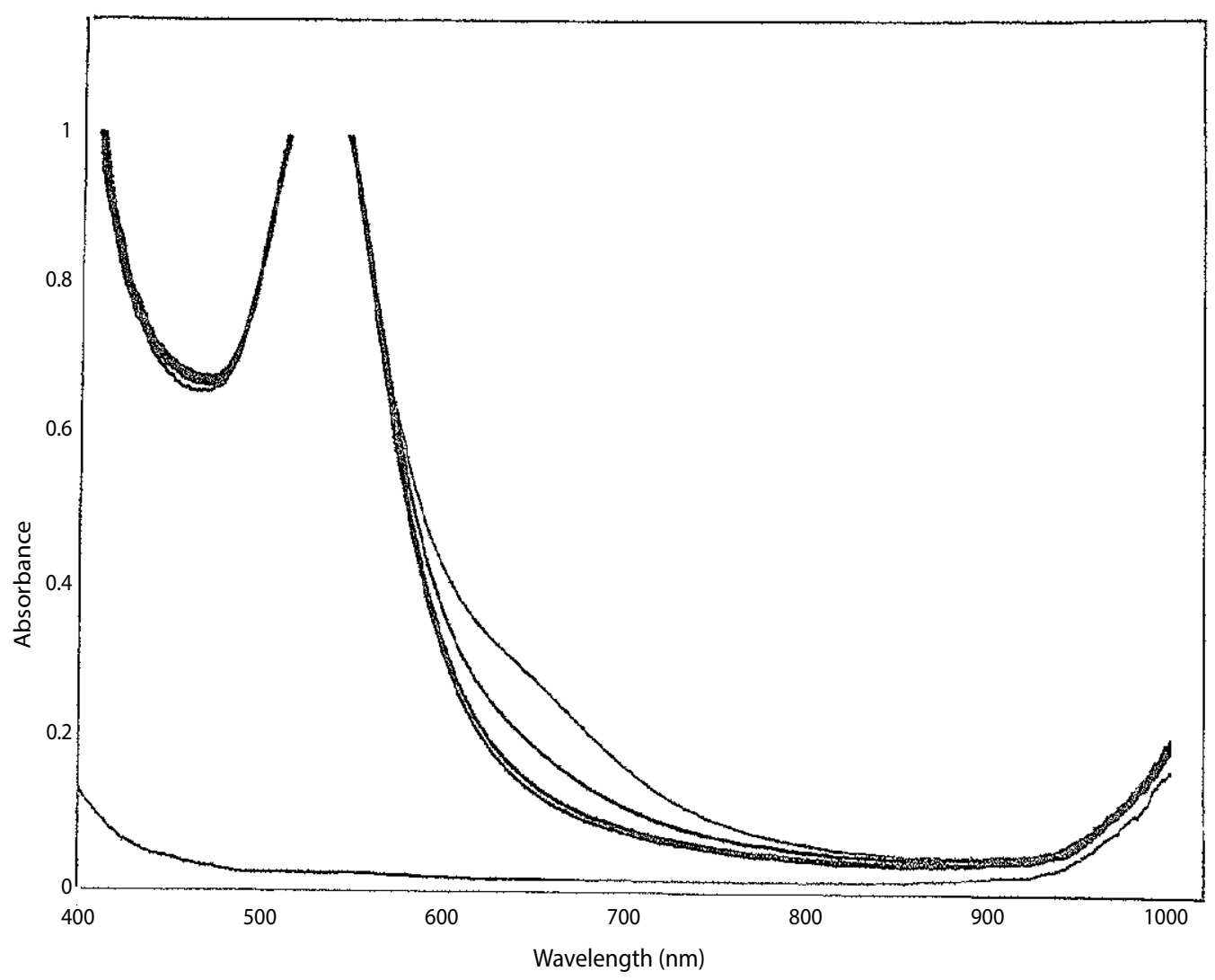

Figure 4: Typical UV-Vis spectra, for raw water sample 4R (Inanda Dam (Wiggins WW), May) with the calibration standards.

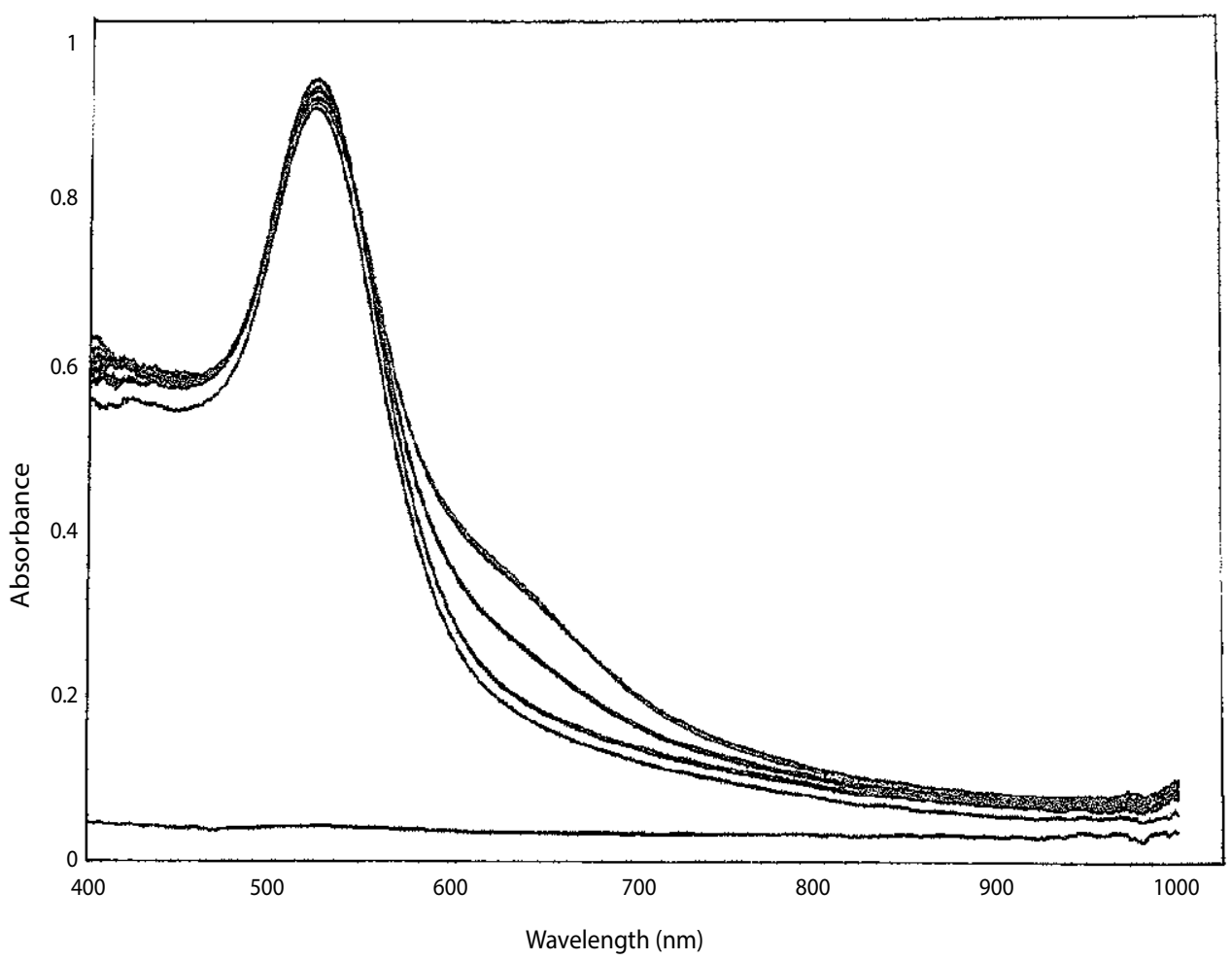

Figure 5: The typical UV-vis spectra, for potable water sample 6F (Inanda Dam (Wiggins), May), with the calibration standards. 
Citation: Manickum T, John W, Toolsee N, Rajagopaul R (2015) Preliminary Performance Evaluation of the Gold Nanoparticle Method for Quantification of Residual Poly-(Diallyldimethyl Ammonium Chloride) in Treated Waters in the Umgeni Water Catchment, Kwazulu-Natal (South Africa). Hydrol Current Res 6: 206. doi:10.4172/2157-7587.1000206

aggregate of poly-DADMAC with gold nanoparticles) against polyDADMAC concentration added to the sample, and then the polyDADMAC concentration is calculated from the equation of the line where the $y$-intercept is equal to zero (Method 1). The second approach is similar, but instead the area of the peak at $690 \mathrm{~nm}$ is used (Method 2). The rationale for using the area is due to the fact that there is a distribution of poly-DADMAC-gold nanoparticle aggregates, and the area could account for the inherent variations with the aggregates [21]. The third method used a similar approach; however, the response parameter was the ratio of the peak absorbance at $690 \mathrm{~nm}$ and at $520 \mathrm{~nm}$ $\left(\mathrm{A}_{690 \mathrm{~nm}} / \mathrm{A}_{520 \mathrm{~nm}}\right)($ Method 3$)$. The ratio method is the preferred method in the literature [24], and as per the earlier work, this method of analysis was also done in order to determine which of the three methods of data analysis provides the most accurate and precise results with the "real world" water samples.

\section{Comparison of assay values for poly-DADMAC obtained by the 3 Methods}

Inspection of the observed assay data for poly-DADAMC on all the water samples indicate, in general, fairly good comparison between the Method 1 and Method 2 values, while the values obtained by Method 3 are much higher (Supplementary Figure B). Considering the LOQ $(\mu \mathrm{g} / \mathrm{L})$ for each of the Methods [21], (1.47 for Method 1, 0.94 for Method 2, 1.64 for Method 3) assay values for samples 7F, 17F, $18 \mathrm{~F}, 19 \mathrm{~F}, 20 \mathrm{~F}, 29 \mathrm{~F}, 30 \mathrm{~F}, 32 \mathrm{~F}, 2 \mathrm{R}, 15,36,38,23 \mathrm{O}$ and $35 \mathrm{O}$ (fourteen in total) were below the LOQ $(1.47 \mu \mathrm{g} / \mathrm{L})$ for Method 1 ; assay values for samples $18 \mathrm{~F}, 29 \mathrm{~F}, 15,28,38,23 \mathrm{O}$ and $35 \mathrm{O}$ (seven in total) were below the LOQ $(0.94 \mu \mathrm{g} / \mathrm{L})$ for Method 2, and assay values for samples $1 \mathrm{R}$, $3 \mathrm{R}, 5 \mathrm{R}, 16,11 \mathrm{O}, 13 \mathrm{O}$ (six in total) were below the LOQ $(1.64 \mu \mathrm{g} / \mathrm{L})$ for Method 3. For both Methods 1 and 3, there was agreement for assay values for six samples: $18 \mathrm{~F}, 29 \mathrm{~F}, 15,38,23 \mathrm{O}$ and $35 \mathrm{O}$, which were below the respective LOQ of the methods. Simple correlation analysis by linear regression of the assay values by all 3 Methods indicated fairly good correlation for assay values obtained by Method 1 and Method 2: $\mathrm{r}^{2}=0.9415(\mathrm{y}=1.059 \mathrm{x}+0.4607)$ (Supplementary Figure A); the corresponding comparison for Method 1 and Method 3 values gave $r^{2}=0.3021(y=2.4848 x+18.394)$, and the Method 2 and Method 3 comparison gave $\mathrm{r}^{2}=0.2504 \quad(\mathrm{y}=1.917 \mathrm{x}+18.949)$, indicating no significant correlation. For confirmation, the statistical data analysis indicated that, for the comparison of poly-DADMAC values obtained by all three Methods (1,2 and 3), there was no significant difference for the poly-DADMAC levels for 31 samples, obtained by Methods 1 and 2 (Supplementary Table B).

\section{Performance evaluation of the analytical test method for poly-DADMAC}

Observed precision of poly-DADMAC concentrations: Except for samples 14 and $12 \mathrm{O}$, all samples $(\mathrm{n}=49)$ were analyzed in triplicate by the three techniques. The instrument precision data indicates that the precision $(\% \mathrm{RSD} \pm \mathrm{SD})$ for Methods $1(18.81 \pm 18.44 \%)$ and Method 2 $(18.05 \pm 17.65 \%)$ exceeds the $\leq 10 \%$ Relative Standard Deviation (RSD) limit used in our internal method validation laboratory procedure. Method $3(3.24 \pm 3.23 \%)$ appears to be the most precise. Based on the $49 \%$ RSD values, the overall mean within-batch precision (\% RSD) $( \pm \mathrm{SD})$ for the triplicate assay values were: $7.42( \pm 7.07)$ for Method 1, $7.66( \pm 7.37)$ for Method 2, and 1.92 (2.71) for Method 3. All three methods thus have repeatability RSD $\leq 10 \%$, and the data indicates that the ratio method (Method 3), with the lowest \%RSD, is the most precise. For those 8 samples that were analysed for $n=2-4$ times, over different days during the three months, the overall mean between- batch reproducibility (\%RSD) $( \pm \mathrm{SD})$ was: $54.37( \pm 30.03)$ for Method 1, $35.89( \pm 34.89)$ for Method 2, and $13.50( \pm 12.64)$ for Method 3. Again, the ratio method (Method 3 ) is the most precise. Our internal laboratory procedure for method validation of analytical test methods, for water, wastewater, and soil/sludge matrix, is based on the criteria in the TR reference document (TR 25-02), published by the local ISO/ IEC 17025 accrediting body South African National Accreditation Standards (SANAS), and is traceable to the ISO/IEC 17025 guide for method development and validation of test methods for testing and calibration laboratories. Our specified precision limit is RSD $\leq 10 \%$. The observed reproducibility precision for Methods 1 and 2 is very much greater than $10 \%$ (54 and 36\%), which exceeds the international limits, whilst that for Method 3 is just over 10\% (13\%), again indicating that the Ratio Method 3 is the most precise. However, it must be noted that the calculated reproducibility precision is based on data over this lengthy three-month ( 90 days - May to July) study period. In the initial report [21], intra and inter-day precision ranged from $0.1-0.7 \%$ RSD for all three methods. However, this precision was obtained on poly-DADMAC standards $(30-90 \mu \mathrm{g} / \mathrm{L})$ in laboratory water, and not on real environmental sample matrix. It is not clear as to the number of different days the reproducibility precision data was obtained. Furthermore, precision data at the lower, reported LOQ $(2 \mu \mathrm{g} / \mathrm{L})$ level for poly-DADMAC, for all three Methods, was not reported [21].

Accuracy of the poly-DADMAC assay values: The method validation data from the initial report [21] indicated recovery values (\%error) of: $87-97 \%$ (-3 to $-12 \%$ ) for Method 1, 92-98\% (-2 to $-8 \%$ ) for Method 2 and $92-89 \%$ (-8 to $-11 \%$ ) on poly-DADMAC solutions $(30 \mu \mathrm{g} / \mathrm{L})$, presumably in ultrapure water matrix, spiked at 10 and $20 \mu \mathrm{g} / \mathrm{L}$. However, no recovery data is reported for blank matrix, or real samples, spiked at less than $10 \mu \mathrm{g} / \mathrm{L}$, and/or at the LOQ level $(\leq 2$ $\mu \mathrm{g} / \mathrm{L})$. The method was also validated for selectivity where solutions containing DADMAC monomer and choline chloride were spiked with poly-DADMAC [21]. One of the major, and significant, raw materials used in poly-DADMAC synthesis, is the DADMAC monomer. Although the actual percentages are not known, it is a known fact that the commercial blends of the organic coagulants do contain some minor level of the DADMAC monomer. Their relative, residual concentration in the potable water will depend on their removal by the water treatment process at each water treatment works, which in turn is influenced by various factors. Polyelectrolyte applications in potable water production and industrial waste water treatment are in the coagulation and flocculation steps, and dewatering of treatment plant sludge. Polyelectrolytes have strong tendency to adsorb onto surface of particles in aqueous suspension, and is the main reason they are widely used in water treatment processes. The water industries are responsible for producing safe drinking water for people and all organisms in rivers, lakes and oceans. To keep water safe, polyelectrolytes are required to mix with turbid natural water for removing solid waste material before filtration. The main aim of introducing polyelectrolytes in water treatment is to induce flocculation and coagulation processes for the removal of suspended solid particles (colloidal matter). All waters, especially surface water, contain both dissolved and suspended particles, which are often assumed to be negatively charged. In suspension, particles repel each other and they cannot come together (stay stable in solution). As a result, they will remain in suspension. Coagulation is the processes where polyelectrolytes are added to destabilize the suspension or affect the surface of water. In coagulation, polyelectrolytes, overcome the factors that keep particles apart such as repulsion forces, and enable the particles to come together to form micro-flocs (flocs are cluster of small particles). In the flocculation 
Citation: Manickum T, John W, Toolsee N, Rajagopaul R (2015) Preliminary Performance Evaluation of the Gold Nanoparticle Method for Quantification of Residual Poly-(Diallyldimethyl Ammonium Chloride) in Treated Waters in the Umgeni Water Catchment, Kwazulu-Natal (South Africa). Hydrol Current Res 6: 206. doi:10.4172/2157-7587.1000206

process, polyelectrolytes are further added to induce the agglomeration of micro-flocs to form macroflocs (bigger particles). The macro-flocs, containing poly-DADMAC, settle or precipitate out of water and are removed as sludge. In our study, the observed values indicate significant poly-DADMAC levels (range: $2-24 \mu \mathrm{g} / \mathrm{L}$ ) for all the raw dam water samples, by all three Methods. These levels are approximately two times higher compared to the corresponding levels in the treated water (range: $2-11 \mu \mathrm{g} / \mathrm{L}$ ). Raw dam water, treated with poly-DADMACcontaining coagulant will be expected to contain some residual polymer present in the potable water, not removed by the sand filtration, or in the final sludge, estimated at $\leq 50 \mu \mathrm{g} / \mathrm{L}$. The observation of the lower levels in the potable water indicates efficiency of the raw water treatment process in removing the added poly-DADMAC coagulant. The observed levels of residual poly-DADMAC on the 4 potable waters in this study indicate compliance to the international limit of $\leq 50 \mu \mathrm{g} / \mathrm{L}$ and accuracy of this gold nanoparticle method. Raw dam water, in the absence of environmental contribution, will not be expected to contain any, or significant levels, of poly-DADMAC. However, the much higher levels noted on our raw water suggests a possible inaccuracy of this gold nanoparticle test method. Alternatively, some other organic compound/s, that are present in the raw dam water, forms an aggregate with the citrate-capped Au-NPs and is subsequently detected by the colorimetric method.

Redox potential: The potential at the boundary (surface of hydrodynamic shear) is the zeta potential. The magnitude of the zeta potential gives an indication of the potential stability of the colloid system. In this study, the zeta potential of the water samples was not determined. The redox potential (or reduction potential) is the tendency of a chemical species to acquire electrons and thereby be reduced. In short, a numerically positive redox potential represents an environment conducive to the oxidation of an introduced substance by reduction of the original media. The redox potential showed a trend of being relatively negative for the raw waters (higher levels of polyDADMAC) and relatively positive for the potable waters (lower levels of poly-DADMAC) (Supplementary Figures E and F). A decrease in zeta potential, towards negative values, was noted for the citratecapped $\mathrm{Au}-\mathrm{NPs}$ (and the other capped Au-NPs) when titrated with TOC as humic acid [25].

\section{Possible sources for the observed levels of apparent poly- DADMAC in the raw water}

Environmental contribution of poly-DADMAC: If the observed levels on the raw dam waters is really due to presence of poly-DADMAC, the corresponding catchment and its associated environmental factors, needs to be considered as a potential source: e.g., residence time, closeness of industries, sewage infiltration, agricultural activity, use of poly-DADMAC, the natural, mechanical mechanism of polyDADMAC-floc aggregate removal by settling to the bottom of the dam by gravity, etc. The four dams supply raw water to the corresponding water treatment plants. The associated environmental data for each dam is summarised in Supplementary Table C. While the process effluent is returned to the Head of Works at Durban Heights (Nagle Dam) (Supplementary Table C), the average poly-(DADMAC) (3.64 $\mu \mathrm{g} / \mathrm{L}$ ) is not very different from that observed for Wiggins WW (Inanda Dam) $(3.40 \mu \mathrm{g} / \mathrm{L})$ (Table 3$)$. Overall, the data indicates fairly negligible possibility of the environment as a source of poly-DADMAC.

Application of gold nanoparticles: Nanoparticles are one of the most important nanomaterials and they are defined as any material with at least one dimension in the $1-100 \mathrm{~nm}$ range. The particle shape may vary and the materials include metals, semiconductors, polymers and carbon based materials. Gold nanoparticles have unique and very interesting physical-chemical properties, especially their optical properties. Like all other metal nanoparticles, Au-NPs undergo plasmon resonance, whereby the frequency of the incident electromagnetic radiation resonates with the oscillation of the delocalised electron cloud present on the nanoparticle surface. The localised surface plasmon resonance frequency lies in the visible range for Au-NPs, and because it is very sensitive to: diameter of the Au-NPs, the surrounding surface chemistry, the aggregation of Au-NPs, it has found use as a probe, or sensor, for the detection of large and small biomolecules, various organic molecules and some inorganic ions [25-30].

Characterisation of the Au-NP complex: When gold nanoparticles are introduced into the poly-DADMAC solution, the intense red colour, (which shows an absorbance peak at $526 \mathrm{~nm}$ ), of the Au-NPs decrease, with a slow appearance of a blue colour. The colour change is due to the shift of the plasmon band to longer wavelengths as the Au-NPs aggregate. The blue colour is attributed to the formation of aggregates between the Au-NPs and poly-DADMAC. Two possible scenarios have been proposed [21] poly-DADMAC has replaced the citrate ions on the surface of the Au-NPs, or, the poly-DADMAC has simply surrounded the citrate ions that are absorbed onto the Au-NPs. The Au-NPs have a high affinity for nitrogen and cationic molecules compared to citrate ions [25-29]. Thus, the former scenario is more likely, where the poly-DADMAC replaces the citrate ion, and destabilises the colloid with aggregate formation. In the current study, the aggregates of AuNPs and poly-DADMAC are characterised by UV-Vis spectroscopy and TEM. In Figure 5, the peak at $526 \mathrm{~nm}$ is due to excess Au-NPs and a second peak at $690 \mathrm{~nm}$, is due to the Au-NP-poly-DADMAC aggregates. The observation of the $164 \mathrm{~nm}$ shift to longer wavelengths is due to the formation of Au-NP-poly-DADMAC aggregates, which was confirmed by TEM analysis [21]. Other changes that can occur with NPs, beside aggregation that can cause a shift in the plasmon peak are: refractive index of the surrounding medium, surface chemistry of the Au-NPs, and changes with Au-NP size or shape [27,29,31]. The particle size analysis of the aggregates revealed that the Au-NPs have a similar morphology, before aggregation $(27 \pm 3 \mathrm{~nm})$ and after aggregation $(28 \pm 3 \mathrm{~nm})$ [21]. The Au-NP optical properties change with the size. Based on size alone, a shift of colour from red to blue occurs when the particle size changes from 3 to $60 \mathrm{~nm}[27,29]$. Thus the shift in the plasmon resonance peak cannot be due to a change in size or shape of the Au-NPs, but it is due to the aggregation of the Au-NPs with polyDADMAC [21].

Natural organic matter (NOM): NOM is a mixture of organic compounds, having diverse chemical properties, which occur in all natural water sources as a result of the breakdown of animal and plant material [32]. Since NOM emanates from different sources, it can be assumed that the composition of NOM in various water sources may not be uniform. NOM can be broadly characterised into: humic substances, microbial by-products and colloid natural organic matter. Humic substances constitute the more hydrophobic fraction of NOM and exhibit relatively high specific ultraviolet absorbance (SUVA) values since the humics usually contain a relatively large proportion of aromatic moieties. Huber et al. reported the characterisation of aquatic (river sample in Germany) humic and non-humic matter using size exclusion chromatography (SEC) [33] into biopolymers, humic substances, building blocks, low molecular weight acids, low molecular weight neutrals and hydrophobic organic carbon. The typical organic content (NOM) of raw dam water is biopolymers, which are very high in summer, and moderate in winter $(250-800 \mu \mathrm{g} / \mathrm{L})$, and humics (moderate: $\pm 2,000 \mu \mathrm{g} / \mathrm{L}$ ) [Huber S, Personal Communication, 2015]. 
Citation: Manickum T, John W, Toolsee N, Rajagopaul R (2015) Preliminary Performance Evaluation of the Gold Nanoparticle Method for Quantification of Residual Poly-(Diallyldimethyl Ammonium Chloride) in Treated Waters in the Umgeni Water Catchment, Kwazulu-Natal (South Africa). Hydrol Current Res 6: 206. doi:10.4172/2157-7587.1000206

Natural organic matter in eight South African water treatment plants, including Wiggins Water Works, of Umgeni Water, was characterized using combined techniques [34,35]. The dissolved organic carbon (DOC) results varied from 3.5-22.6 $\mathrm{mg} / \mathrm{L}$, indicating the extent of variation of NOM quantities in the different regions where the samples were obtained. The advanced techniques used indicated that the samples contained mainly humic substances, while some had marine humic and non-humic substances.

Reactions of NOM with Au-NPs: Nason et al. [35] studied the interactions between NOM and gold nanoparticles, stabilized with different organic capping agents, like anionic citrate, neutral polyvinylpyrrolidone, and cationic mercapto (trimethylammonium). Another report appeared on the gold(III) and Au-NPs interactions with humic acids $[35,36]$. A study on effects of NOM type and concentration on the aggregation of citrate-stabilized Au-NPs was further reported by Nason et al. [37]. They showed that four different NOM isolates act to stabilize citrate Au-NPs with respect to aggregation. The resulting stability appears to be due to adsorption of the NOM onto the surfaces of the NPs; the exact nature of the interactions between NOM and the coated Au-NPs is however, unclear. Both the type and concentration of $\mathrm{NOM}$, along with the ionic strength of the system are important factors in determining the colloid stability.

Possible explanation for apparent poly-DADMAC levels in the Umgeni Water catchment (raw dam waters): NOM can be broadly characterized into: humic substances (HS), microbial by-products (composed of acids, with high charge density, polysaccharides, amino sugars, proteins), and colloidal natural organic matter (contain relatively polar amino sugars). Treatment of raw dam water, containing, inter alia, NOM, and other matter, with coagulant, like poly-DADMAC, removes NOM, and other matter, by floc formation, and subsequent filtration. Untreated raw dam water, not treated with coagulant, will contain the same concentration of NOM, and other matter.

The Au-NP colorimetric method, in this study, uses $20 \mathrm{~mL}$ of a suspension of about 200 particles per $410 \mathrm{~mL}$, equivalent to \pm 10 particles per sample/test. Examination of the typical UV-Vis spectrum of the gold nanoparticle solutions mixed with various concentrations of poly-DADMAC standards $(10-100 \mu \mathrm{g} / \mathrm{L})$ [21] shows the presence of the peak for the Au-NPs, at $520 \mathrm{~nm}$, and the Au-NP-poly-DADMAC aggregate $(690 \mathrm{~nm})$, suggesting an excess amount of Au-NPs is still available for possible aggregate formation with other organic compounds, even at $100 \mu \mathrm{g} / \mathrm{L}$ poly-DADMAC concentration. Based on the earlier studies [35-37], we therefore propose that, on addition of $\mathrm{Au}-\mathrm{NPs}$ to the raw water sample, there is some interaction of the NOM and $\mathrm{Au}-\mathrm{NPs}$ to form aggregates, which are subsequently detected as "poly-DADMAC", by the colorimetric analytical method employed for determination of residual poly-DADMAC. Presumably, the Au-NP(NOM) aggregate absorbs at the same wavelength of $690 \mathrm{~nm}$, as the Au-NP-(poly-DADMAC) aggregate.

Influence of sample collection from different sites at different times: This is an important factor that must be considered in the evaluation of the analytical results obtained, and the subsequent conclusions made in this study. The grab, raw and potable, water samples in this study were collected over a 3-month period, from the designated sample sites, but on different days, and at different times. The day-today variation (\%RSD) for water quality indices, and for residual poly-DADMAC levels, can therefore be expected to be fairly large. For example, for raw water, the \%RSD for TOC ranges from $5-19 \%$, and is $12-19 \%$ for potable water. For raw water, the \%RSD for the apparent poly-DADMAC levels, by Method 1, ranges from
$12-132 \%$, and is fairly similar for potable water: $45-114 \%$. The much higher variation in poly-DADMAC levels, in both raw and potable water, compared to variation for both a raw and potable, water quality index, can be due in part to, amongst others, the following factors: the much smaller number of samples $(n=3-4$, for poly-DADMAC, Table 3 ), compared to $n=90$ (for TOC, Table 1), and the relatively higher inherent imprecision noted for Method 1 (absorbance of peak at 690 $\mathrm{nm}$ ) and Method 2 (area of peak at $60 \mathrm{~nm}$ ), variation in the NOM levels in the various water samples taken.

Earlier work on poly-DADMAC quantitation in river water: Gumbi et al. [21] reported relatively lower levels of poly-DADMAC (not detected/2-2.1 $\mu \mathrm{g} / \mathrm{L}$ ) on samples $(\mathrm{n}=8)$ from the Umgeni River, in KwaZulu-Natal, using the same citrate-capped, gold nanoparticle colorimetric method. Again, one would not expect any, or significant, levels of poly-DADMAC, in natural river water. The corresponding TDS levels for these river samples were correspondingly lower: (mean) $( \pm \mathrm{SD}) 41( \pm 25) \mathrm{mg} / \mathrm{L}$ (range=18-69); the TOC levels on these river samples were not, however, reported [21]. For our raw dam waters, we observed an average TOC level of $2.6( \pm 0.40) \mathrm{mg} / \mathrm{L}$ for the raw waters. The apparent mean poly-DADMAC levels measured were $6.6 \mu \mathrm{g} / \mathrm{L}$ (range $=<2$ to $17 \mu \mathrm{g} / \mathrm{L}$ ), with much higher TDS levels of $144( \pm 68) \mathrm{mg} / \mathrm{L}$ (range $=65-244$ ). Based on our findings in this study, the possibility exists similarly that the apparent levels of $2 \mu \mathrm{g} / \mathrm{L}$ noted in the earlier report [21] could be likely due to a relatively lower level of NOM (not reported) in river water, which forms an aggregate with the citratecapped Au-NPs, and is detected by the UV-Vis colorimetric method.

Removal of NOM from water: Krause, et al. [32], in their characterisation of NOM in South Africa, investigated the use of cyclodextrin polyurethanes for NOM removal; the hydrophobic basic fraction and the hydrophilic acid fraction were most efficiently removed (24 and 10\% respectively). The use of strong base anion exchange resin in the sample, about $10 \mathrm{~g} / 50 \mathrm{~mL}$, and shaking overnight [Huber S, 2015, Personal Communication] may remove most of the NOM while poly-DADMAC should stay in solution; the resin is cationic in charge and should repulse poly-DADMAC.

\section{Evaluation of the application of the developed Au-NP colorimetric method}

Although citrate-Au-NPs were synthesised in the present study, they are commercially available from NanoComposix Inc. and nationally (South Africa) $\left(1.67 \times 10^{11}-1.97 \times 10^{11}\right.$ particles $\left./ \mathrm{mL}\right)$, but at substantial cost: $\pm \mathrm{R} 266$ per $20 \mathrm{~mL} / \mathrm{sample}$. Beside this reagent cost, there are no other major reagent costs. The capital costs of the required equipment are affordable $( \pm 7394$ Euros). Regarding the method performance, detailed data has been previously reported [22]. The linearity range was between 0 and $30 \mu \mathrm{g} / \mathrm{L}$ with $\mathrm{r}^{2}=0.99$ in all cases. The method LOD and LOQ $(\mu \mathrm{g} / \mathrm{L})$ was 0.49 and 1.47 for Method 1 (absorbance of peak at $690 \mathrm{~nm}$ ), 0.31 and 0.94 for Method 2 (area of peak at $690 \mathrm{~nm}$ ) and 0.54 and 1.64 for Method 3 (ratio of the absorbance of peaks at 690 and $520 \mathrm{~nm}\left(\mathrm{~A}_{690 \mathrm{~nm}} / \mathrm{A}_{520 \mathrm{~nm}}\right)$, indicating that Method 2 is the most sensitive. However, all three Methods are fairly sensitive, for the quantification of residual poly-DADMAC as the international maximum limit is about 25 times higher. However, the recovery (and percentage error) at this level was not reported [22]. The Method detection level (MDL) has been defined as follows: "the constituent concentration that, when processed through the complete method, produces a signal with a $99 \%$ probability that it is different from the blank. For seven replicates of the sample, the mean must be 3.14 s above the blank where $s$ is the standard deviation of the seven replicates...The MDL will be larger than the LLD... Recoveries should 
Citation: Manickum T, John W, Toolsee N, Rajagopaul R (2015) Preliminary Performance Evaluation of the Gold Nanoparticle Method for Quantification of Residual Poly-(Diallyldimethyl Ammonium Chloride) in Treated Waters in the Umgeni Water Catchment, Kwazulu-Natal (South Africa). Hydrol Current Res 6: 206. doi:10.4172/2157-7587.1000206

Page 13 of 15

be between 50 and $150 \%$ and $\%$ RSD values $\leq 20 \% \ldots$... [38,39]. The Level of quantitation (LOQ) (Minimum quantitation level (MQL)) has also been defined as follows: "the constituent concentration that produces a signal sufficiently greater than the blank that it can be detected within specified levels...Typically it is the concentration that produces a signal $10 s$ above the reagent water blank signal" [38].

The IUPAC method [39] uses the mean concentration and standard deviation from replicate analysis of a "blank" (ultrapure water) sample matrix, as per following equations: mean+10 SD, for LOQ, and mean +3 SD, for Limit of Detection (LOD), respectively. This statistical approach, however, cannot be applied when a negative value is observed for the signal response for the blank sample. The serial dilution technique, although it results in higher LOD and LOQ, would tend to be more accurate, being based on compliance to actual recovery, and precision, limits; selection of the "noise" region in a chromatogram, using the $\mathrm{S} / \mathrm{N}$ method, is subjective, due to choice by the analyst. The computed instrument precision (\% RSD) $( \pm$ SD) was 18.05 ( \pm 17.65$)$. The overall mean within-batch precision (\% RSD) for the triplicate assay values were: $7.42( \pm 7.07)$ for Method 1, $7.66( \pm 7.37)$ for Method 2, and 1.92 (2.71) for Method 3, which complies with our internal limit of $\leq 10 \%$ RSD for method validation. The overall mean between-batch reproducibility was, however $\geq 10 \%$ RSD for all three calibration methods:\% RSD $( \pm$ SD): $54.37( \pm 30.03)$ for Method 1, 35.89 $( \pm 34.89)$ for Method 2, and $13.50( \pm 12.64)$ for Method 3. Method 3 was the most precise, and most inaccurate. Compared to other analytical methods, like colloid titration and gravimetry, this gold nanoparticle method is much faster, is far less labour-intensive and is much more sensitive.

\section{Correlation analysis between observed residual poly- DADMAC levels and water quality parameters}

The average poly-DADMAC levels, obtained by all three calibration methods (M1, M2, M3) on all raw and potable water, were compared with the corresponding average $\mathrm{pH}$, conductivity, turbidity, TDS and TOC values. The results of all the statistical data analysis is summarised in Supplementary Table D. Due to the fairly good correlation of polyDADMAC levels obtained by M1 and M2, any comparisons, and their possible significance, between poly-DADMAC levels obtained by M3 and water quality parameters can be ignored.

Raw water: For raw water, there was a strong positive linear relationship between: the apparent poly-DADMAC (M1) level and TOC, poly-DADMAC (M1, M2) level and $\mathrm{pH}$, and poly-DADMAC (M1, M2) level and turbidity. A strong negative relationship between: the apparent poly-DADMCAC (M1, M2) level and Conductivity, polyDADMAC (M1, M2) level and TDS, poly-DADMAC (M1, M2) level and Redox Potential was observed.

It was subsequently proposed that the observed, apparent polyDADMAC levels are due to the presence and reaction of NOM with the Au-NPs. In such a case, it can be expected that water quality parameters, like TOC, TDS, conductivity (NOM contains some charged material) and turbidity of water would increase as the apparent poly-DADMAC (NOM, indicated by the TOC level) levels increase. However, a strong negative relationship is noted for the comparison with conductivity and TDS. In the absence of actual NOM levels, there will be obvious uncertainty in these comparisons. Particles that occur in natural waters are almost always negatively charged. Thus, as apparent poly-DADMAC (NOM) levels increase, redox potential will decrease (shift toward negative values). The raw water $\mathrm{pH}$ for the four dams ranged from 6.8-7.1. Acidic $\mathrm{pH}$ is known to destabilise citrate- capped Au-NPs [30]. Gumbi et al. [22] showed that varying the $\mathrm{pH}$ (6-9) did not have any significant effect on absorbance or area for this colorimetric method for poly-DADMAC analysis. It would appear that NOM behaves similarly to poly-DADMAC, so that an increase in apparent poly-DADMAC level is noted with increasing $\mathrm{pH}$.

Potable water: For potable water, there was a strong positive linear relationship between: the poly-DADMAC (M1, M3) level and TOC, poly-DADMAC (M1, M2) (level) and Redox potential. A strong negative relationship between the poly-DADMCAC (M1, M2, and M3) level and $\mathrm{pH}$ was noted. The TOC levels can be expected to increase with an increase in poly-DADMAC (organic material) levels. Poly-DADMAC is a cationic (positively charged) polymer. Hence, an increase in level would be expected to result in increasing (positive) Redox potential. The potable water $\mathrm{pH}$ for the four treated dam waters ranged from 6.8-6.9, which is not very different to that of the corresponding raw waters, and it falls within the reported stable range studied [21]. Although the sample numbers in this study is rather small $(\mathrm{n}=4)$, it would appear that optimum levels of poly-DADMAC (3.4-3.6 $\mathrm{mg} / \mathrm{L}$ ) are observed at average water $\mathrm{pH} 6.77$ (Nagle Dam) and 6.79 (Inanda Dam).

Possible relationship between NOM and poly-DADMAC: Grab raw and potable water samples in this study were collected over a 3-month period, from the designated sample sites, but on different days, and at different times. The day-to-day variation (\%RSD) for water quality indices, and for poly-DADMAC levels, can therefore be expected to be fairly large. For example, for raw water, the \%RSD for TOC ranges from $5-19 \%$, and is $12-19 \%$ for potable water. For raw water, the \%RSD for the apparent poly-DADMAC levels, by Method 1, ranges from $12-132 \%$, and is fairly similar for potable water: $45-114 \%$. The much higher variation in poly-DADMAC levels, in both raw and potable water, compared to variation for both a raw and potable, water quality index, can be due in part to, amongst others, the following factors: the much smaller number of samples $(n=3-4$, for polyDADMAC, Table 3), compared to $\mathrm{n}=90$ (for TOC, Table 1), and the relatively higher inherent imprecision noted for Method 1 (absorbance of peak at $690 \mathrm{~nm}$ ) and Method 2 (area of peak at $60 \mathrm{~nm}$ ), variation in the NOM levels in the various water samples taken. The TOC value is approximately equal to the NOM value for natural waters. Humic acid, a component of NOM, has been suggested as a standard for mimicking NOM in the laboratory. In the performance of Total Organic Carbon (TOC) analysis, UV persulfate instrumentation demonstrated $95 \%$ recovery of humic acid consistently across a linear range of 1 to 100 ppm $\mathrm{C}$, the range typically found in the NOM of source water. In this study, there is a strong positive linear relationship between the polyDADMAClevel (determined by M1) and TOC, for both raw and potable water. The NOM levels were not determined analytically in this study. We can therefore expect some positive linear relationship between the NOM (not measured here) and poly-DADMAC levels. The observed/ measured TOC levels can be used as an approximate indicator of the actual NOM levels. Raw dam water, not treated with coagulant, will contain NOM and other material, whereas potable water, treated with coagulant, will contain a much lower level of NOM and other material, due to the effect of the coagulant during the water treatment process. Subsequently, the apparent poly-DADMAC levels, from reaction of NOM with the Au-NPs, would be expected to be greater for the raw water, compared to the potable water. The TOC levels are, in general, expected to be greater for raw water (contains NOM, various organic matter, etc.) compared to treated, potable water (added coagulant aids in NOM, organic matter, etc. removal via flocculation-coagulation during the water treatment process). This is evident for each of the four 
Citation: Manickum T, John W, Toolsee N, Rajagopaul R (2015) Preliminary Performance Evaluation of the Gold Nanoparticle Method for Quantification of Residual Poly-(Diallyldimethyl Ammonium Chloride) in Treated Waters in the Umgeni Water Catchment, Kwazulu-Natal (South Africa). Hydrol Current Res 6: 206. doi:10.4172/2157-7587.1000206

Page 14 of 15

dams. The TOC levels are as follows (raw vs. potable $-\mathrm{mg} / \mathrm{L}$ ): Inanda: 2.59 vs. 2.33 ; Nagle: 2.31 vs. 2.16 ; Hazelmere: 2.48 vs. 1.91 ; Wiggins: 3.17 vs. 2.04. We would therefore expect the NOM levels for the raw dam waters to exceed that for the treated potable water. Subsequently, the apparent (false positive) poly-DADMAC levels noted for raw water, from the proposed reaction of NOM in raw water, with the Au-NPs, would be expected to be greater than the actual true level of residual poly-DADMAC in the treated potable water (which contains a relatively lower of level of NOM, organic matter, etc.). The source of residual poly-DADMAC in the treated water is from the initially added coagulant $(0.08-5 \mathrm{mg} / \mathrm{L})$ during the water treatment process, and is expected to be $\leq 50 \mu \mathrm{g} / \mathrm{L}$, the international limit. The latter is observed in this study. The observed poly-DADMAC levels are as follows (raw vs. potable $-\mu \mathrm{g} / \mathrm{L}$ (Method 1): Midmar: 10.12 vs. 1.22 ; Hazelmere: 6.82 vs. 1.21; Nagle: 5.73 vs. 3.64 ; Inanda: 3.73 vs. 3.40 . Compared to the other 3 dams, the average raw water turbidity for Inanda dam is distinctly the lowest $(1.04 \pm 0.30 \mathrm{NTU})$, and so is the corresponding coagulant dosing level (0.08-1.01 mg/L) (Table 3) required. Hence there is no significant difference in the apparent poly-DADMAC level in the raw water (3.73), and the treated water (3.40). A combined plot of TOC (converted to $\mu \mathrm{g} / \mathrm{L}$ units) (x-axis) vs. poly-DADMAC concentration (y-axis) indicated a significant positive linear relationship: $\mathrm{r}^{2}=0.8017$. We can therefore expect a significant positive linear relationship between the actual NOM and poly-DADMAC levels.

\section{Degradation of poly-DADMAC}

Detailed stability studies on poly-DADMAC were conducted by John [19], under different experimental conditions of exposure to temperature (ambient to $80^{\circ} \mathrm{C} / 30 \mathrm{~min}$ ), $\mathrm{pH}$ variations (2-12/1 hr.), UV radiation $\left(365 \mathrm{~nm} / 24 \mathrm{hr}\right.$.) and ozone. At $80^{\circ} \mathrm{C}$ there was clear change in polymer structure. At $\mathrm{pH} 12$, there was a noted decrease in the polymer peak area, but peak shape and MWD remained essentially unchanged. The UV radiation study showed evidence of polymer degradation. In essence, the GPC results indicated that poly-DADMAC is a very stable polymer and undergoes change only when subjected to extremes of $\mathrm{pH}$, temperature and UV conditions, which are unlikely to be experienced under environmental conditions, and during the normal course of water treatment processes. The stability data on poly-DADMAC indicate very little or no effect on the validity or accuracy of our observed study results.

\section{Conclusion}

The current real world study indicates that the citrate-capped gold nanoparticle colorimetric method, using the calibration of peak absorbance at $690 \mathrm{~nm}$ (Method 1), or peak area at $690 \mathrm{~nm}$ (Method 2 ), is suitable for quantification of residual poly-DADMAC in potable water, treated with the poly-DADMAC coagulant. However, raw dam water, containing NOM, and possibly any other organic matter that may be present, apparently forms an aggregate with the citrate-capped Au-NPs, which absorbs at the same $690 \mathrm{~nm}$ wavelength as that of the Au-NP-poly-DADMAC aggregate and is subsequently detected by the UV-Vis colorimetric method. The test method was found to be sensitive $(\mathrm{LOQ}=0.9-1.6 \mu \mathrm{g} / \mathrm{L})$, linear $\left(\mathrm{r}^{2}=0.99\right)$ and accurate over the range $0-30 \mu \mathrm{g} / \mathrm{L}$ for quantification of residual poly-DADMAC in treated, potable water. However, the instrument and inter-day method precision exceeded the internal limit of being $\geq 10 \%$ RSD. For potable water, there was a strong positive linear relationship between: polyDADMAC levels and: TOC, Redox potential, and a strong negative, linear relationship between poly-DADMCAC levels and PH. Future research work must consider (inter alia): (1) improvement of the instrument and inter-day precision of the colorimetric analytical method: The observed instrument precision $(\% \mathrm{RSD}( \pm \mathrm{SD})$, for Method 1 (absorbance of peak at $690 \mathrm{~nm}$ ) and Method 2 (area of peak at $690 \mathrm{~nm})$, was $18.05( \pm 17.65)$ and $18.81( \pm 18.44)$, respectively, which exceed the typical $\leq 10 \%$ limit. The overall mean between-batch (reproducibility) $\%$ RSD was: $54.37( \pm 30.03)$ for Method 1, $35.89( \pm 34.89)$ for Method 2, and $13.50( \pm 12.64)$ for Method 3 ; (2) evaluation of the recovery at the observed LOQ: No recovery data for blank matrix or real samples, is reported in the original method [21], at spike levels less than $10 \mu \mathrm{g} / \mathrm{L}$ down to $2 \mu \mathrm{g} / \mathrm{L}$ of poly-DADMAC; (3) use of other organic capping agents, (e.g., tannic acid, polyvinylpyrrolidone): The current method development, and application, is based on the use of only citrate-capped gold nanoparticles; (4) efficient sample preparation methods for NOM removal from raw dam water The use of cyclodextrin polyurethanes for NOM removal was shown to achieve $10-24 \%$ NOM removal from raw water, in one South African study. The proposed use of strong base anion exchange resin, to remove most of the NOM, is one possible option; (5) transfer of this analytical to a real raw water treatment plant for application: The determination of residual poly-DADMAC in treated water is useful for at least two reasons: (1) establishment of over-dosing with the coagulant and (2) establishment of water quality compliancehealth risk assessment, regarding the international allowable limit of a residual of $\leq 50 \mu \mathrm{g} / \mathrm{L}$. The initially reported method development work, and this current study, was undertaken at laboratory scale, in an academic (university), and process evaluation, setting; (6) application of this same Au-NP colorimetric method to quantification of NOM, or other organic matter, present in raw dam water: The current study has shown possible interference by NOM, present in untreated raw dam water, by its reaction with the Au-NPs, in the analysis of polyDADMAC. NOM in natural water can be quantified using size exclusion chromatography-organic carbon detection-organic nitrogen detection (LC-OCD-OND) [40]; (7) toxicity assessment studies of residual poly-DADMAC, and disinfection by-products (DBPs): polyDADMAC can be toxic to aquatic organisms at levels above $50 \mu \mathrm{g} / \mathrm{L}$, and has potential to form $N$-nitrosodimethylamine (NDMA), which is a disinfection by-product, and a suspected carcinogen.

\section{Acknowledgements}

The authors acknowledges: $\mathrm{Mr} \mathrm{N}$ Dladla and $\mathrm{Mr} \mathrm{L}$ Mthembu (Process Technicians, Wiggins Process Evaluation Facility, Umgeni Water), Dr P Ndungu, Lecturer, (UKZN) for the poly-DADMAC analyses, analytical test method information and other useful comments related to the test results, Mr S Terry (Scientist, Water Quality \& Environmental Services, Umgeni Water), for providing some of the supplementary information, Mr J Ramjith (Biostatistician/Lecturer University of Cape Town, South Africa), for the statistical data analysis, and the Innovative Research Development Committee (IRDC) (Umgeni Water), for funding the cost of the poly-DADMAC analyses.

\section{References}

1. Bolto B, Gregory J (2007) Organic polyelectrolytes in water treatment. Water Res 41: 2301-2324.

2. Majam S, Thompson PA (2006) Polyelectrolyte determination in drinking water Water SA 32: 705-707.

3. Jin F, Hu J, Yang M, Jin X, He W, et al. (2006) Determination of diallyldimethylammonium chloride in drinking water by reversed-phase ion-pair chromatography-electrospray ionization mass spectrometry. J Chromatogr A 1101: 222-225.

4. Becker NSC, Bennet DM, Bolto BA, Dixon DR, Eldridge RJ, et al. (2004) Detection of polyelectrolytes at trace levels in water by fluorescent tagging React Funct Poly 60: 183-193.

5. Nozaic DJ, Freese SD, Thompson P (2001) Longterm experience in the use of polymeric coagulants at Umgeni Water. Water Sci Technol: Water Supply 1: 43-50.

6. Bond T, Templeton MR, Graham N (2012) Precursors of nitrogenous 
Citation: Manickum T, John W, Toolsee N, Rajagopaul R (2015) Preliminary Performance Evaluation of the Gold Nanoparticle Method for Quantification of Residual Poly-(Diallyldimethyl Ammonium Chloride) in Treated Waters in the Umgeni Water Catchment, Kwazulu-Natal (South Africa). Hydrol Current Res 6: 206. doi:10.4172/2157-7587.1000206

disinfection by-products in drinking water--a critical review and analysis. below J Hazard Mater 235-236: 1-16.

7. Shah AD, Mitch WA (2012) Halonitroalkanes, halonitriles, haloamides, and $\mathrm{N}$-nitrosamines: a critical review of nitrogenous disinfection byproduct formation pathways. Environ Sci Technol 46: 119-131.

8. Sharma VK (2012) "Kinetics and Mechanism of Formation and Destruction of N-Nitrosodimethylamine in Water - A Review". Sep Purif Technol 88: 1-10.

9. Choi J, Valentine RL (2002) Formation of N-nitrosodimethylamine (NDMA) from reaction of monochloramine: a new disinfection by-product. Water Res 36: 817-824.

10. Padhye L, Luzinova Y, Cho M, Mizaikoff B, Kim JH, et al. (2011) PolyDADMAC and dimethylamine as precursors of $\mathrm{N}$-nitrosodimethylamine during ozonation: reaction kinetics and mechanisms. Environ Sci Technol 45: 4353-4359.

11. Park SH, Wei S, Mizaikoff B, Taylor AE, Favero C, et al. (2009) Degradation of amine-based water treatment polymers during chloramination as $\mathrm{N}$-nitrosodimethylamine (NDMA) precursors. Environ Sci Technol 43: 13601366.

12. Cumming J, Hawker D, Chapman H, Nugent K (2011) Water, Air, Soil Pollut 216: $441-450$.

13. Cumming JL, Hawker DW, Nugent KW, Chapman HF (2008) Ecotoxicities of polyquarterniums and their associated polyelectrolyte-surfactant aggregates (PSA) to Gambusia holbrooki. J Environ Sci Health, Part A: Toxic/Hazard Subst. Environ Eng 43: 113-117.

14. NSF Fact Sheet -Polyelectrolytes and NSF/ANSI Standard 60 (2010) National Sanitation Foundation International: 12.

15. Letterman RD, Pero RW (1990) Contaminants in polyelectrolytes used in water treatment. J Amer Water Works Assoc 82: 87-97.

16. Cumming JL, Hawker DW, Matthews C, Chapman HF, Nugent K (2010) Toxicol Environ Chem 92: 1595-1608.

17. American Water Works Association (1993) Standard for Poly DADMAC, ANSI/ AWWA B451-9, revision of ANSI/AWWA B451-87, Colorado.

18. John W (2008) Synthesis, properties and analysis of polydadmac for water purification. Ph D Thesis.

19. John W, Buckley CA, Jacobs EP, Sanderson DR (2015) Analysis of polydadmac by off-line membrane filtration gel permeation chromatography.

20. Mwangi IW, Ngila JC, Ndungu P (2012) A new spectrophotometric method for determination of residual polydiallyldimethylammonium chloride flocculant in treated water based on a diazotization-coupled ion pair. Water SA 38: 707-714.

21. Gumbi B, Ngila JC, Ndungu PG (2014) Gold nanoparticles for the quantification of very low levels of poly-diallyldimethlyammonium chloride in river water. Analytical Methods 6: 6963-6972.

22. Turkevich J, Stevenson PC, Hillier J (1951) A study of the nucleation and growth processes in the synthesis of colloidal gold. Discuss Faraday Soc 11: 55-75.

23. Toolsee N (2010) Jar Test procedure. Umgeni Water (Pietermaritzburg), Intranet; E\&SS/PS/Proc/10.
24. Haiss W, Thanh NT, Aveyard J, Fernig DG (2007) Determination of size and concentration of gold nanoparticles from UV-vis spectra. below Anal Chem 79 4215-4221.

25. Liu W, Zhang D, Tang Y, Wang Y, Yan F, et al. (2012) Highly sensitive and selective colorimetric detection of cartap residue in agricultural products. Talanta 101: 382-387.

26. Menon SK, Mistry BR, Joshi KV, Sutariya PG, Patel RV (2012) Analytica detection and method development of anticancer drug Gemcitabine $\mathrm{HCl}$ using gold nanoparticles. Spectrochim Acta A Mol Biomol Spectrosc 94: 235-242.

27. Ray PC (2010) Size and shape dependent second order nonlinear optica properties of nanomaterials and their application in biological and chemical sensing. Chem Rev 110: 5332-5365.

28. Vilela D, Gonzalez MC, Escarpa A (2012) Sensing colorimetric approaches based on gold and silver nanoparticles aggregation: Chemical creativity beyond the assay. A review. Anal Chim Acta $751: 24-43$

29. Wang Z, Ma L (2009) Gold nanoparticle probes. Coord Chem Rev 253: 1607 1618.

30. Zhou Y, Yang Z, Xu M (2012) Colorimetric detection of lysine using gold nanoparticles aggregation. Anal Methods 4: 2711-2714.

31. Sun L, Liu D, Wang Z (2008) Functional gold nanoparticle-peptide complexes as cell-targeting agents. Langmuir 24: 10293-10297.

32. Nkambule TL, Krause RWM, Mamba BB, Haarhoff J (2009) Characterisation of natural organic matter (NOM) and its removal using cyclodextrin polyurethanes. Water SA 35: 200-203.

33. Huber SA, Balz A, Abert M, Pronk W (2011) Characterisation of aquatic humic and non-humic matter with size-exclusion chromatography--organic carbon detection--organic nitrogen detection (LC-OCD-OND). Water Res 45: 879-885.

34. Nkambule TL, Krause RWM, Haarhoff J, Mamba BB (2012) Natural organic matter in South African waters: NOM characterization using combined assessment techniques, Water SA 38: 1-16.

35. Stankus DP, Lohse SE, Hutchison JE, Nason JA (2010) Interactions between natural organic matter and gold nanoparticles stabilized with different organic capping agents. Environmental Science \& Technology 45: 3238-3244

36. Pefia-Mendez EM, Moreno FJ, Abizanda AIJ, Gonzalez JEC, Leon JJA, et al (2011) Gold (III) and gold nanoparticles interactions with humic acids.

37. Nason JA, McDowell SA, Callahan TW (2012) Effects of natural organic matter type and concentration on the aggregation of citrate-stabilized gold nanoparticles. J Environ Monit 14: 1885-1892.

38. Eaton AD, Clesceri LS, Rice EW, Greenberg AE (eds) (2005) Standard methods for the examination of water and wastewater, $\left(21^{\text {st }} \mathrm{dn}\right)$ USA. Introduction: Glossary 1010 C and Quality Assurance 1020: 1-, 1-60.

39. Long GL, Winefordner JD (1983) Limit of detection: a closer look at the IUPAC definition. Anal Chem 55: 712A-724A.

40. Huber SA, Balz A, Abert M, Pronk W (2011) Characterisation of aquatic humic and non-humic matter with size-exclusion chromatography--organic carbon detection--organic nitrogen detection (LC-OCD-OND). Water Res 45: 879-885. 